\title{
Article \\ Cutting Oxygen Production-Related Greenhouse Gas Emissions by Improved Compression Heat Management in a Cryogenic Air Separation Unit
}

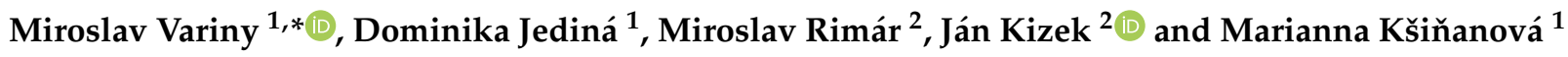 \\ 1 Department of Chemical and Biochemical Engineering, Faculty of Chemical and Food Technology, \\ Slovak University of Technology in Bratislava, Radlinského 9, 81237 Bratislava, Slovakia; \\ domka444@gmail.com (D.J.); m.ksinanova1@gmail.com (M.K.) \\ 2 Department of Process Technique, Faculty of Manufacturing Technologies with a Seat in Presov, \\ Technical University of Kosice, Bayerova 1, 08001 Presov, Slovakia; miroslav.rimar@tuke.sk (M.R.); \\ jan.kizek@tuke.sk (J.K.) \\ * Correspondence: miroslav.variny@stuba.sk
}

check for updates

Citation: Variny, M.; Jediná, D.; Rimár, M.; Kizek, J.; Kšiňanová, M. Cutting Oxygen Production-Related Greenhouse Gas Emissions by Improved Compression Heat Management in a Cryogenic Air Separation Unit. Int. J. Environ. Res. Public Health 2021, 18, 10370. https:// doi.org/10.3390/ijerph181910370

Academic Editor: Jacek Koziel

Received: 9 September 2021

Accepted: 28 September 2021

Published: 1 October 2021

Publisher's Note: MDPI stays neutral with regard to jurisdictional claims in published maps and institutional affiliations.

Copyright: (c) 2021 by the authors. Licensee MDPI, Basel, Switzerland. This article is an open access article distributed under the terms and conditions of the Creative Commons Attribution (CC BY) license (https:/ / creativecommons.org/licenses/by/ $4.0 /)$.

\begin{abstract}
Oxygen production in cryogenic air separation units is related to a significant carbon footprint and its supply in the medicinal sphere became critical during the recent COVID-19 crisis. An improved unit design was proposed, utilizing a part of waste heat produced during air precooling and intercooling via absorption coolers, to reduce power consumption. Variable ambient air humidity impact on compressed air dryers' regeneration was also considered. A steady-state process simulation of a model $500 \mathrm{t} \mathrm{h}^{-1}$ inlet cryogenic air separation unit was performed in Aspen Plus ${ }^{\circledR}$ V11. Comparison of a model without and with absorption coolers yielded an achievable reduction in power consumption for air compression and air dryer regeneration by 6 to $9 \%$ (23 to $33 \mathrm{GWh}$ year $^{-1}$ ) and a favorable simple payback period of 4 to 10 years, both depending on air pressure loss in additional heat exchangers to be installed. The resulting specific oxygen production decrease amounted to EUR 2-4.2 $\mathrm{t}^{-1}$. Emissions of major gaseous pollutants from power production were both calculated by an in-house developed thermal power plant model and adopted from literature. A power consumption cut was translated into the following annual greenhouse gas emission reduction: $\mathrm{CO}_{2} 16$ to 30 kilotons, $\mathrm{CO} 0.3$ to 2.3 tons, $\mathrm{SO}_{\mathrm{x}} 4.7$ to 187 tons and $\mathrm{NO}_{\mathrm{x}} 11$ to 56 tons, depending on applied fossil fuel-based emission factors. Considering a more renewable energy sources-containing energy mix, annual greenhouse gas emissions decreased by 50 to over $80 \%$, varying for individual pollutants.
\end{abstract}

Keywords: air separation unit; air humidity; emissions; power consumption; emission factors; heat recuperation; absorption cooler; compressed air dryer

\section{Introduction}

Oxygen is one of the most important technical gases produced worldwide. Oxygen production plants rely on its separation from air by cryogenics [1], membranes [2], or adsorption [3] with the first method being suitable for large-scale production of almost pure oxygen and other gases from air [4,5] the latter two, suitable as mobile oxygen or nitrogen sources are still in development [6,7]. Typical energy consumption in cryogenic units exceeds $200 \mathrm{kWh}$ of electricity per ton of produced oxygen [8,9] and is thus associated with significant environmental impact $[1,10]$.

As calculated by Banaszkiewicz and Chorowski [3], minimum thermodynamic work for air separation is around $51 \mathrm{kWh}$ per ton of produced oxygen, which documents the large gap between actual plant performance and minimum energy requirement while highlighting the potential for specific power consumption reduction. At the same time, calculations of vacuum pressure adsorption indicated energy consumption as low as 
$140 \mathrm{kWh}$ per ton of produced 95\% grade oxygen; however, data from real applications [3] show lowest values to be almost three times higher, significantly exceeding those reported from cryogenic units. Calculations performed by Castillo [11] and Markewitz et al. [12] for membrane-based air separation units indicate achievable energy savings of up to $9 \%$ compared to conventional cryogenic units. Such systems are especially suitable for oxyfuel power plants.

Further significant reduction in specific power consumption is expected from thermochemical air separation cycles using perovskite oxides [13] and their powering either by solar irradiation [14] or low-grade heat [15]. They can be further combined with adsorptionbased air pre-treatment to reach comparable oxygen (or nitrogen) purity as cryogenics but with a significantly lower carbon footprint [16].

Oxygen is widely used in metallurgy $[8,17,18]$, cutting down fuel costs and greenhouse gas emissions $[19,20]$, for oxy-combustion coupled with carbon capture and storage $[9,21]$, production of a variety of chemicals, and in medicine [22,23].

Oxygen production and supply have recently attracted global attention due to the COVID-19 pandemic and the associated significant rise in medicinal oxygen demand [24]. Strained oxygen supplies remain critical nowadays, especially in India and Africa [25-27]. Alternative methods of medicinal oxygen production have been tested successfully [28]; however, many hospitals and healthcare facilities rely on a high-percentage oxygen supply from large cryogenic air separation units (ASU). While its supply is in the spotlight of the media, its carbon footprint has received far less attention [29]. A recent study by Balys et al. [30] identifies this knowledge gap and sums up evidence of the environmental impact related to medicinal oxygen supply chain considering $64,800 \mathrm{~m}^{3}$ per month medicinal grade oxygen consumption in a hospital. As documented, the global warming potential (GWP) of liquid tank oxygen delivered is around $260 \mathrm{gCO}_{2} \mathrm{~kg}^{-1}$ while oxygen delivery in cylinders shows much higher environmental impact with a GWP value of over $550 \mathrm{gCO}_{2} \mathrm{~kg}^{-1}$. In-house oxygen production via pressure swing adsorption shows a somewhat lower GWP value than cylinder delivery but still much higher than liquid oxygen delivery in tanks. These figures fit well with the specific energy consumption values provided above: assuming average power production emission factor of a coal power plant of $0.8 \mathrm{tCO}_{2} \mathrm{MWh}^{-1}$ [31] and average specific power consumption of $300 \mathrm{kWh} \mathrm{t}_{\mathrm{O} 2}{ }^{-1}$, oxygen emission factor of $240 \mathrm{gCO}_{2} \mathrm{~kg}^{-1}$ of oxygen is obtained, the difference between this value and the oxygen GWP estimated by Balys et al. [30] can be attributed to oxygen losses and emissions due to oxygen transport and logistics. This stresses the importance of oxygen production energy intensity reduction as the related greenhouse gas emissions represent a large portion of total oxygen supply chain-related emissions.

\subsection{Improving the Design and Operation of Cryogenic Air Separation Units}

Air separation in cryogenic plants is a well-established technology enabling production of pure gases from air [32,33] with an oxygen production capacity above $5000 \mathrm{Nm}^{3} \mathrm{~h}^{-1}$ [34]. Its basic layout includes double- or triple-stage air compression with intercooling, compressed air cooling, and removal of residual moisture together with carbon dioxide on a suitable adsorbent [35,36]. Dry, compressed air is then routed to the cryogenic part of the plant, where a single- to triple-column design is usually adopted to obtain one or more gases of over 95 (99) \% purity [34]. Thermal coupling of the columns, as well as incorporation of expanders for pressure energy recovery, help reduce the plant's energy demand [32,37]. Likewise, air pre-treatment by membranes [38,39] or adsorbers [40] can reduce both capital and operational costs of the cryogenic part.

A major part of the energy demand of a conventional cryogenic unit can be allocated to the compression section due to the need to compress air from atmospheric pressure to typically 500 to $700 \mathrm{kPa}$ [32]. Minor energy consumption of up to 10 to $15 \%$ of the total value is associated with adsorbent (air dryer) regeneration. Power consumption in the cryogenic section is negligible and it is associated with process pumps operation and, if process expanders driving generators are integrated in the unit, it can even reach zero. 
Therefore, most operation optimization studies focus on compression and purification sections looking for possibilities of a power consumption cut, while optimal design studies also include the cryogenic part of the plant.

Many recent studies have already focused on the reduction in the plant's carbon footprint, either by improving the design or by deeper integration within industrial clusters $[4,40,41]$. These studies are often performed in expert simulation software, e.g., Aspen Plus or Aspen Hysys [42,43]. Adamson et al. [5] published a framework for steady state operation optimization of three ASU and the related gas network comprising multiple compressors based on load scheduling achieving electric energy consumption reduction of $5 \%$. Singla and Chowdhury [8] optimized oxygen production costs in an integrated iron and steel mill by ASU's cryogenic section reconfiguration and oxygen purity adjustment. Compared to the original layout, oxygen production costs were reduced by 15 to $25 \%$ in the improved set-up while keeping the single-column plant design. Wang et al. [1] investigated various column heat integration schemes and compared their energy consumption to the conventional plant layout, concluding that a partly heat-integrated design is the most suitable, ensuring carbon emissions cut by over $40 \%$ and a reasonable decrease in total annual costs.

Air compression before cryogenic separation results in a significant amount of waste heat that is usually disposed of by water intercoolers and coolers [44]. Rong et al. [45,46] analyzed the possibilities of compression heat recovery and reuse through inlet air cooling and dehumidification. They found that the proposed system, incorporating a desiccant wheel and an organic Rankine vapor compression refrigeration cycle helped reducing the energy costs of a model ASU by $5 \%$ with a payback period of around 5 years. Other researchers studied options for compression heat reuse in an oxy-fuel power plant, finding its optimal allocation in fuel pre-drying [39] and feedwater preheating train [4]. Similarly, Escudero et al. modeled integration of an oxy-fuel plant coupled with carbon capture and storage into energy system of a fluid catalytic cracking unit [47]. Air compression heat was partly utilized for low temperature boiler feedwater heating, while compressed air pre-cooling and intercooling was enhanced by compression cooling system installation. Zhou et al. proposed using air compression heat to drive an organic Rankine cycle [48] that in turn drove a compression cooling unit for air pre-cooling, thus reducing the power demand of the model ASU by over $4 \%$. As energy demand for air cooling is tightly interconnected with air properties, especially with its humidity, the effect of its variations on the achievable power consumption reduction is of key importance but remains largely unexplored.

\subsection{Greenhouse Gas Emissions Attributable to ASU Operation}

Air separation units consume electric energy produced either on-site (if integrated in an oxyfuel power plant) or elsewhere, which is more common. Making the operation of an ASU more efficient thus means cutting down its greenhouse gas (GHG) emissions. Carbon dioxide emissions are considered as the most relevant ones in this regard and a lively debate on the correct attitude towards calculation and evaluation of its emission factors is in progress $[49,50]$. It is generally agreed that marginal emission factors (MEF) should better represent the real impact of power consumption change on the related $\mathrm{CO}_{2}$ emissions [51,52]. For even more precise carbon accounting for processes with very variable power demand, daily or even hourly MEF are recommended to be applied [53]. Several analyses attempted to assign energy consumption and the associated GHG emissions to industrial branches [54] and society spheres [55] and to formulate suitable emission factors predictions for decades ahead [56,57]. Even though power production becomes gradually cleaner as advanced techniques and flue gas cleaning systems are adopted in thermal plants and old plants are ruled out of service [58], MEF values were agreed to be highly spatiotemporally specific. Thus, recent studies employing the MEF always relate them to a specific period and country [52,59], thus requiring reliable structural data about power sources and transmission system operation [60]. A recent extensive review by Hamels et al. [49] evaluating over 100 related studies revealed both the absence of a 
unified approach to the estimation of GHG emissions related to power production and consumption and the significant variability of individual emission factors.

\subsection{Aims of the Study}

As results from the performed literature survey, intense research on optimal design and operation of cryogenic ASU is in progress worldwide. Especially for standalone ASUs it is imperative to exploit all possibilities for power consumption reduction offered by heat recuperation and reuse. Although the possibility of using compression heat has been analyzed in recent studies, the effect of inlet air humidity has to be studied further. The associated cut in power consumption and, thus, in GHG emissions should be clearly quantified. However, no unified approach to this topic has been presented up to now. Instead of using a single power emission factor, applying a range of its values yields more realistic, even if less precise, results.

To fill the identified knowledge gap, the following aims are pursued in our study:

- Analyzing possible power consumption reduction by using compression heat for air pre-cooling and intercooling via absorption coolers $(\mathrm{ACH})$;

- Investigating the effect of air cooling on energy consumption for adsorptive air dryer regeneration and evaluating the associated impact of variable air humidity using measured hourly data;

- Estimating basic economic parameters of ACH installation in a model ASU;

- Analyzing and quantifying achievable reduction in carbon dioxide, nitrogen oxides, sulfur oxides, and carbon monoxide by applying various emission factors reported in literature as well as those obtained by modeling of an industrial thermal power plant operation.

The study method includes modeling of an ASU with basic layout and parameters adopted from [36] in Aspen Plus ${ }^{\circledR}$ (Aspen Plus V 11, Aspen Technology Inc., Bedford, MA, USA),

- $\quad$ starting with basic design and verification of the values,

- introducing model changes, incorporating adsorption coolers and cooling water towers,

- testing the sensitivity of energy savings by proposed technology changes to frictional pressure losses and analyzing energy consumption for adsorptive air dryers' regeneration.

Subsequently, a set of measured ambient air properties data in form of hourly averages from one-year period was used to recalculate the achievable power consumption cut to estimate a simple payback period of the proposed $\mathrm{ACH}$ installation. In the end, an industrial thermal power plant model was set up considering publicly available data on the associated emissions of air pollutants, yielding power emission factors for carbon dioxide, nitrogen oxides, sulfur oxides, and carbon monoxide. The obtained values were compared with data available in relevant literature and by their implementation, a range of achievable cuts in GHG emissions was calculated for every considered pollutant. Thereby a complex energetic-economic-environmental view on oxygen production in cryogenic ASUs is provided.

\section{Materials and Methods}

\subsection{Air Separation Unit Model}

A basic cryogenic ASU model is completely based on a study by Hamayun et al. [36] which aimed to identify the most suitable two-column cryogenic air separation unit configuration by evaluating seven alternatives based on exergy analysis. For each alternative configuration of two-column cryogenic air separation unit, a rigorous mathematical model was developed and simulated using Aspen Plus ${ }^{\circledR}$ V10 (Aspen Technology Inc., Bedford, MA, USA). The results showed that the design alternative labelled as "C1" was the most exergy-efficient for cryogenic air separation, and therefore this design alternative was used to develop the basic mathematical model in program Aspen Plus ${ }^{\circledR}$ V11 in the current study. 
A simple flow diagram of two-column cryogenic ASU model design (C1) is presented in Figure 1.

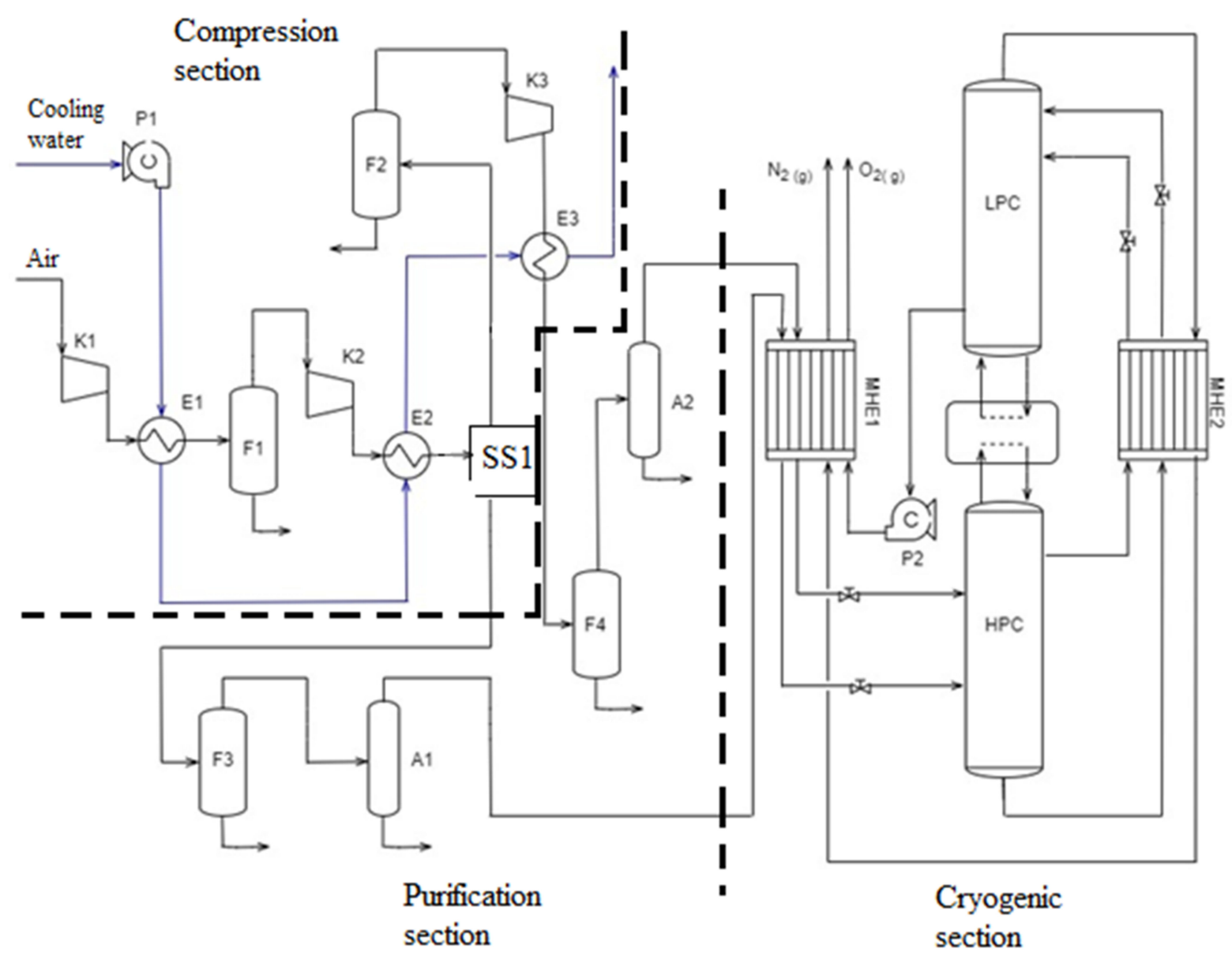

Figure 1. Simple flow diagram of two-column cryogenic air separation model design C1, adapted from [36]. A1,2: adsorbers; E1-3: heat exchangers; F1-4: phase separators; HPC: high-pressure column; K1-3: compressors; LPC: low-pressure column; MHE1,2: multi-stream heat exchangers; P1,2: pumps; SS1: stream splitter. Dashed lines = borders of unit's sections.

The model consists of three main sections: compression, purification, and cryogenic. Compression section consists of three compressors (K1, K2, K3), water cooled intercoolers (E1, E2, E3) and flash separators (F1, F2, F3 and F4) for condensed water removal from cooled compressed air. After the second compression stage, compressed air is separated into two streams with optimal mass ratio of 1:2 as discussed in [36]. Purification section consists of two adsorbers (A1, A2), where residual water vapor and carbon dioxide are removed from compressed air by adsorption before entering the cryogenic section. Cryogenic section is composed of two multi-stream heat exchangers (MHE1, MHE2), where air is cooled and liquified using product streams from the distillation section and two distillation columns-high pressure column (HPC) and low-pressure column (LPC). The columns are heat-integrated in a standard way for two-column cryogenic distillation-the condenser duty of the HPC column equals the reboiler duty of the LPC column.

All input model parameters of inlet material streams, main process equipment, thermodynamic model standard Peng-Robinson and other assumptions were adopted from [36], including the following assumptions and simplifications:

- Steady state;

- Isentropic efficiency of compressors: $72 \%$;

- Isentropic efficiency of pump: $80 \%$;

- Pressure loss in all heat exchangers: $10 \mathrm{kPa}$;

- Outlet air temperature in water coolers: $40^{\circ} \mathrm{C}$; 
- Number of stages in HPC column: 60;

- Position of feed stages in HPC column: 50 and 60;

- Number of stages in LPC column: 60;

- Position of feed stages in LPC column: 1 and 42;

- Total pressure loss in HPC column: $20 \mathrm{kPa}$;

- Total pressure loss in LPC column: $30 \mathrm{kPa}$;

- Zero heat (and cold) losses from all modeled process equipment surfaces.

Atmospheric air is the main inlet raw material stream. Further model specifications are provided in Appendix A, including properties of air (Table A1) and cooling water (Table A2). Each process equipment of the selected cryogenic ASU design was modeled by the most suitable model available in Aspen Plus ${ }^{\circledR}$ V11. An overview of selected models and required input model parameters is shown in Appendix A, Table A3.

\subsection{Process Flow Diagram of Cryogenic Air Separation Unit}

A process flow diagram presents a graphical form of the developed mathematical model and relates to the basic model of cryogenic ASU described in previous text and is provided in Figure 2.

Critical analysis of model parameters showed that the pressure loss in both adsorbers and adsorption heat of water were neglected in [36]. Therefore, two additional adjustments of input model parameters were necessary:

(1) Specification of air pressure loss in adsorbers A1 and A2 according to the pressure loss specified in all modeled heat exchangers $=10 \mathrm{kPa}$.

(2) Addition of fictive heat exchangers E4 and E5 to the basic model downstream of adsorbers A1, A2 to include the effect of adsorption heat of water. The most suitable value of adsorption heat of $3000 \mathrm{~kJ} \mathrm{~kg}^{-1}$ was specified according to [61].

Mathematical model modified in Aspen Plus ${ }^{\circledR}$ V11 is presented in Appendix A, Figure A1.

\subsection{Regeneration of Air Dryers}

Calculation of power input for adsorbers regeneration was based on referential parameters obtained from available technical documentation of real adsorbers with a similar size [62], assuming that the same means of regeneration were adopted for both referential and model adsorbers (electric heating of inlet air). Approximate electrical power input for model adsorbers regeneration, $Q_{p, \text { model }}$, was calculated from known electrical power input for referential adsorber regeneration $\left(Q_{p, r e f}=165 \mathrm{~kW}\right)$ and mass flow of adsorbed water in referential adsorber $\left(\dot{m}_{\mathrm{H} 2 \mathrm{O}, \text { ref }}=102.6 \mathrm{~kg} \mathrm{~h}^{-1}\right)$ and known mass flow of adsorbed water in modeled adsorber, $\dot{m}_{\mathrm{H} 2 \mathrm{O}, \text { model }}$, Equation (1).

$$
Q_{p, \text { model }}=\frac{\dot{m}_{H 2 \mathrm{O}, \text { model }}}{\dot{m}_{\mathrm{H} 2 \mathrm{O}, \text { ref }}} Q_{p, \text { ref }}
$$

\subsection{Model with Absorption Cooling}

The basic model of cryogenic ASU shows potential for compression section design improvement. Additional cooling of compressed air before the first compression stage and after the first and second compression stages to temperatures lower than model values can thus be considered. In case of additional cooling of compressed air, more condensed water from air and significant energy savings for adsorbers regeneration due to lower amount of adsorbed water is presumed. Compression work reduction is also expected.

Two design improvement possibilities were considered:

- Using own (internal) available heat for cold production.

- Using external available heat and cold. 

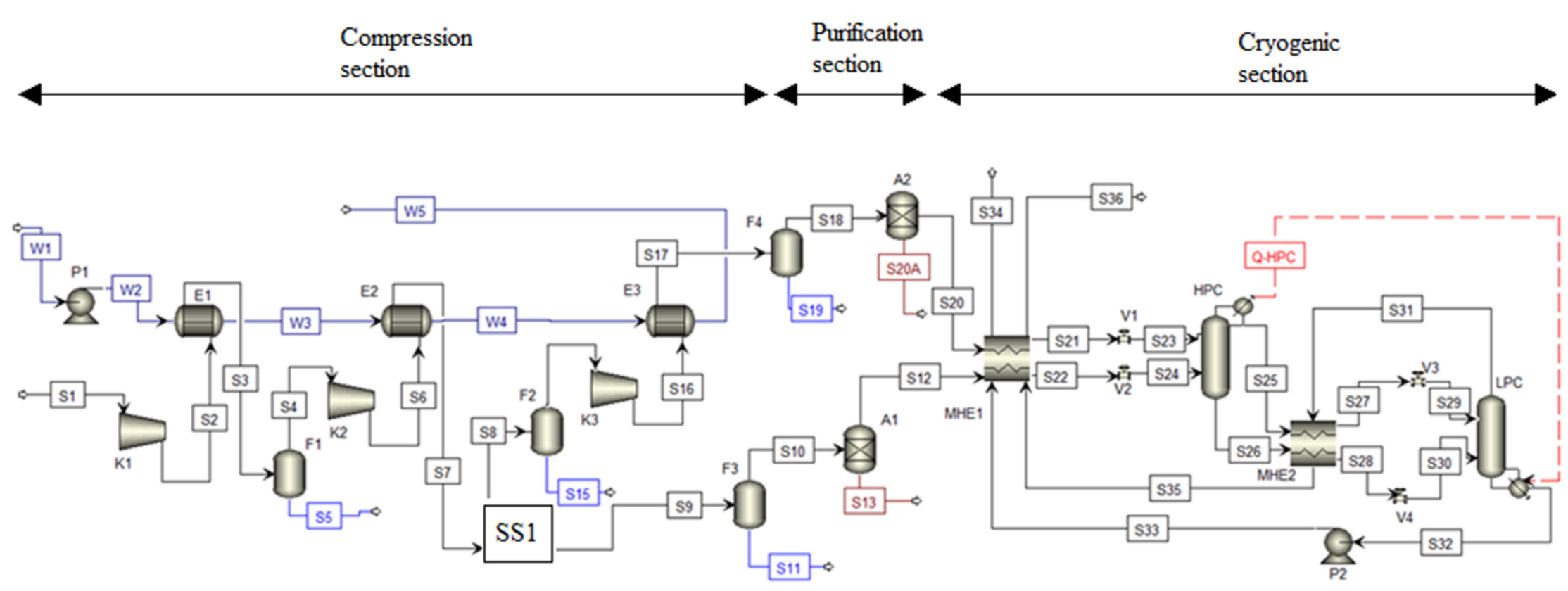

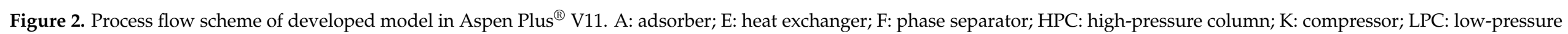
column; MHE: multi-stream heat exchanger; Q: heat flow; P: pump; S: material stream; SS1: stream splitter; V: valve; W: cooling water stream. 


\subsubsection{Own (Internal) Heat for Cold Production}

All heat content of compressed air was absorbed by cooling water in intercoolers (E1, E2, E3) in the basic technology. The proposal was to use heat potential obtained in hot compressed air stream after the first and second compression stage as a source of energy for hot-water $\mathrm{ACH}$ for additional cooling of compressed air before the next compression stage. Thus, reduction in compression work in compressors K2 and K3 due to lower inlet air temperature is achieved. Heat released by $\mathrm{ACH}$ is led away by available cooling water. Additional utilization of cooling water offered potential for cooling towers implementation into the basic mathematical model to secure a closed loop cooling water system.

The most suitable technical parameters of hot-water $\mathrm{ACH}$ for the modeled system were obtained from available technical documentation [63] and are presented in Appendix B, Tables A4 and A5.

The most suitable model parameters for cooling towers were obtained from available technical documentation [64] of real cooling towers for large volumes of water. According to the available technical documentation, four identical cooling towers to cool cooling water back to the input process temperature of $25^{\circ} \mathrm{C}$ were designed. Their selected technical parameters are presented in Appendix B, Table A6.

For standard mathematical modeling of cooling towers in Aspen Plus, a RadFrac model with a few equilibrium stages considering neither reboiler nor condenser was used. The RadFrac model calculates the liquid and vapor/gas equilibrium on each equilibrium stage using property package NRTL [65], which was specified for all cooling water systems. Input model parameters of cooling tower are presented in Appendix B, Table A7. Input parameters for air were specified according to input model parameters of inlet air stream S1.

\subsubsection{External Heat for Cold Production}

The aim of this analysis was to evaluate the possibility of pre-cooling inlet air stream $\mathrm{S} 1$ before entering the first compression stage to achieve reduction in compression work of compressor $\mathrm{K} 1$ by absorption cooling of inlet air stream to temperatures below $25^{\circ} \mathrm{C}$.

It is assumed that energy required for absorption cooler operation includes available waste, zero cost, heat from a nearby industrial plant. This assumption is justified, as low-grade waste heat, suitable for this purpose, is commonly found in heavy industry (iron and steel, refining, pulp and paper, cement and lime and others). A study by Brueckner et al. [66] revealed that at least 127 PJ per annum (13\% to total industrial fuel energy consumption) waste heat is available in German industry with more than $80 \%$ at temperatures above $100^{\circ} \mathrm{C}$. Similarly, tens of PJ per annum of recoverable waste heat were reported by Law et al. [67] for the UK industry.

Simultaneously, absorption and condensation heat from $\mathrm{ACH}$ is led away by cooling water. Input model parameters of suitable hot-water ACH shown in Appendix B, Table A8, were obtained from available technical documentation of a real ACH [63].

Process flow diagram of mathematical model comprising air pre-cooling and intercooling enhanced by absorption cooling is presented in Figure 3. ACH and the necessary new heat exchangers are included as follows: E14, E15-water cooling of $\mathrm{ACH}$ absorbers and condensers; E0, E8, E12-air coolers utilizing cooled water from $\mathrm{ACH}$; E7, E11-ACH generators; E6, E10- hot compressed air coolers for hot water production for $\mathrm{ACH}$. 


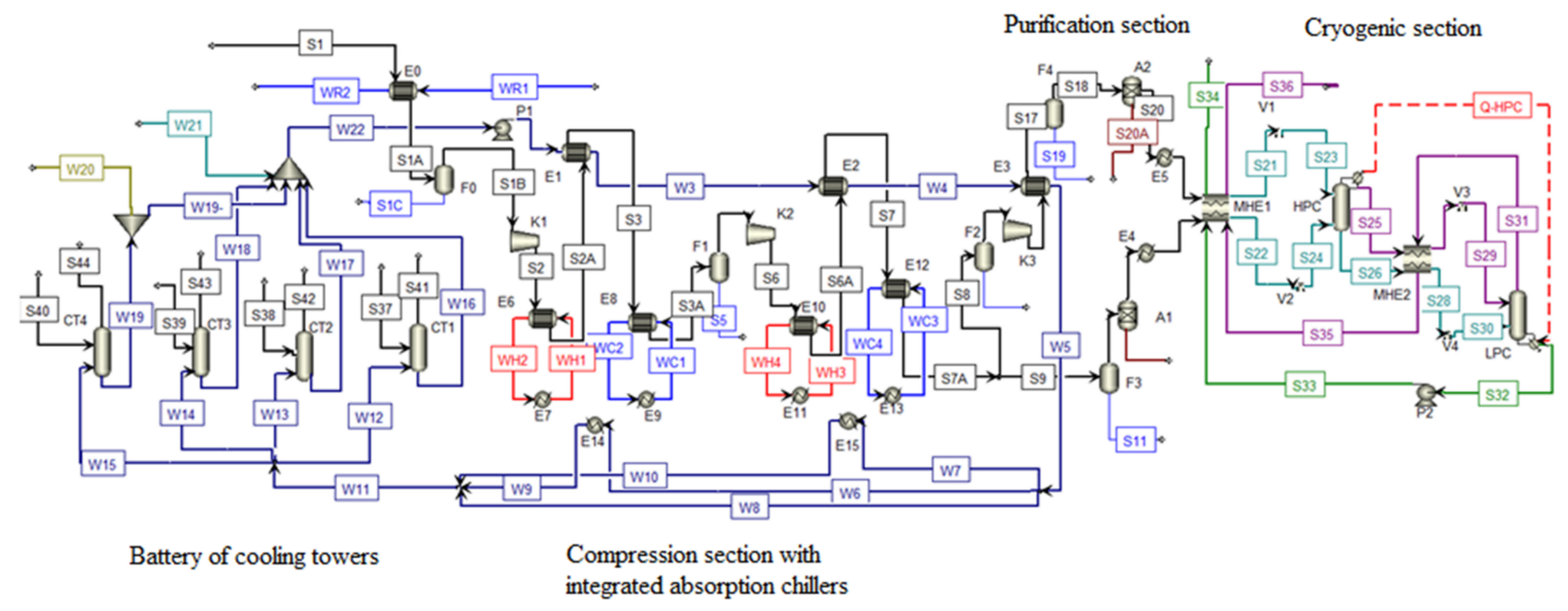

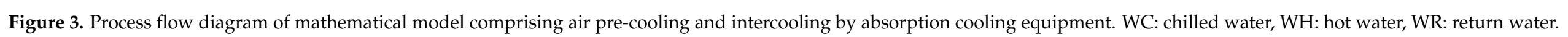




\subsection{Ambient Air Properties Dataset}

Air properties dataset comprised a period from January 2020 to December 2020. It included hourly average values of atmospheric pressure, temperature, and relative humidity for location Košice-Center: altitude: $213 \mathrm{~m}$ above sea level, northern latitude: $48^{\circ} 43^{\prime} 41^{\prime \prime}$, eastern longitude: $21^{\circ} 15^{\prime} 54^{\prime \prime}$, Slovakia. Measured data were recalculated to yield air humidity, $\mathrm{Y}$, in grams of water vapor present in air per one kilogram of dry air and are plotted in Figures 4-6 as monthly data series.

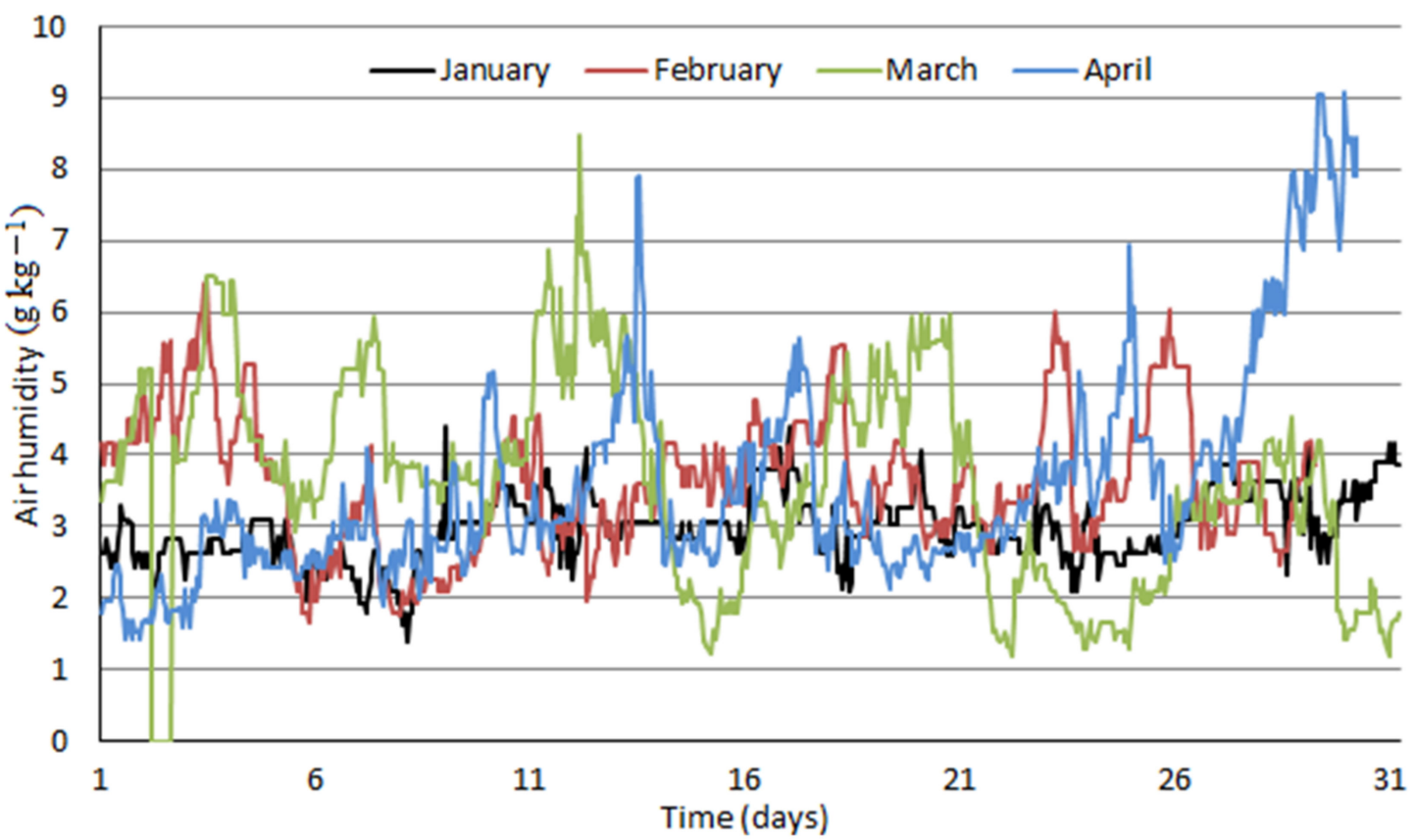

Figure 4. Hourly averages of air humidity in Košice-Center from January 2020 to April 2020.

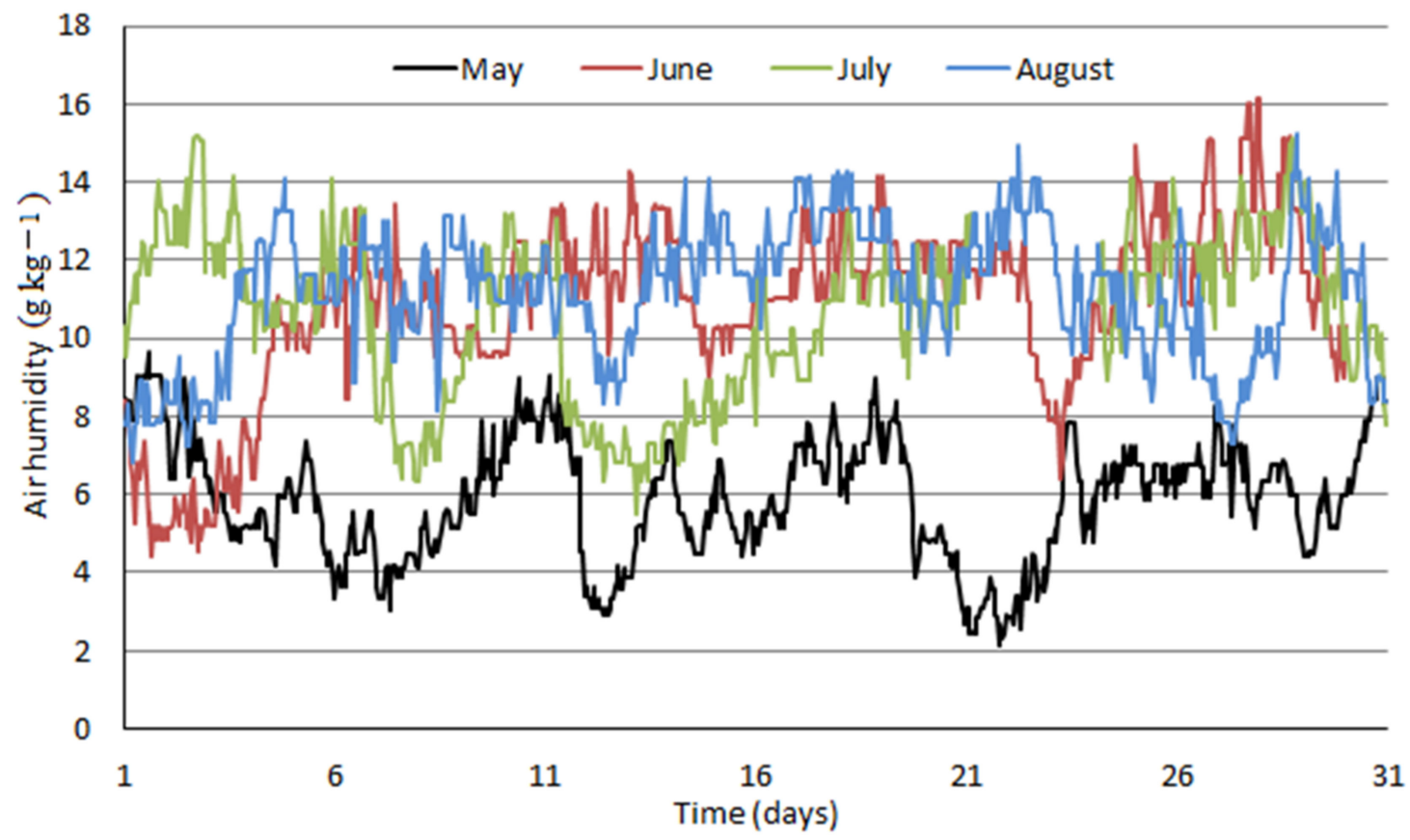

Figure 5. Hourly averages of air humidity in Košice-Center from May 2020 to August 2020. 


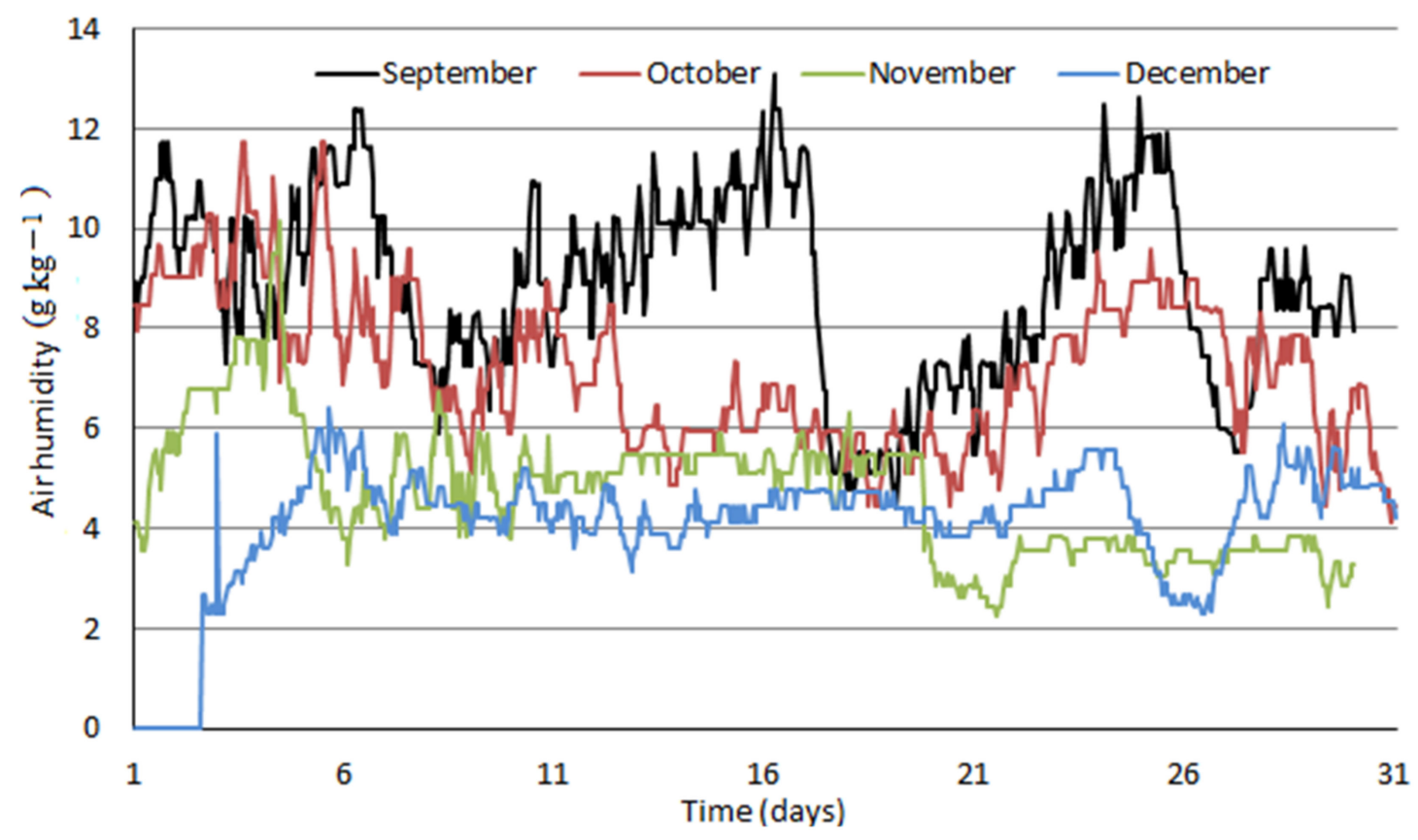

Figure 6. Hourly averages of air humidity in Košice-Center from September 2020 to December 2020.

Figures 4-6 clearly distinguish between winter and summer months in terms of air humidity. Values around 2 to $4 \mathrm{~g} \mathrm{~kg}^{-1}$ are typical for winter months; air humidity increases quickly within one or two months to typical summer values of 10 to $14 \mathrm{~g} \mathrm{~kg}^{-1}$. Fluctuating humidity values affect the distribution of water removal between compressed air intercoolers and final adsorbers which is further influenced by enhanced air cooling by $\mathrm{ACH}$ proposed in this study.

\subsection{Economic Calculations}

For economic analysis, approximative investment costs of additional process equipment- $\mathrm{ACH}$ and five heat exchangers-were estimated. Approximate cost of ACH was obtained from available technical documentation [68] of real absorption coolers. The size of reference ACH is characterized by "cooling capacity", which unit is equal to unit USRT (U.S. refrigeration ton). Additionally, model ACH obtained from technical documentation [63] are characterized by unit USRT, USRT model, which is very close to the USRT of reference absorption coolers, $U S R T_{r e f}$ and, thus, enables linear cost recalculation without significant deviation from the generally used power law (cost dependence on specific equipment size to the power of 0.6 to 0.8 ). The cost of model $\mathrm{ACH}, \mathrm{Cost}_{\text {model }}$, can be estimated using Equation (2).

$$
\text { Cost }_{\text {model }}=\frac{U S R T_{\text {model }}}{\text { USRT }_{\text {ref }}} \text { Cost }_{r e f}
$$

Calculated cost of model ACH is for 2016; its actual cost for 2020, Cost 2020 , was calculated via the CEPCI index (Chemical Engineering Plant Cost Index), Equation (3), adopting the calculation procedure used in reference cost engineering literature [69]. An overview of parameters for model ACH investment cost estimation is presented in Table 1.

$$
\operatorname{Cost}_{2020}=\frac{C E P C I_{2020}}{C E P C I_{2016}} \text { Cost }_{2016}
$$


Table 1. Estimation of ACH investment costs. ACH: absorption cooler, CEPCI: Chemical Engineering Plant Cost Index, USRT: U. S. Refrigeration Ton.

\begin{tabular}{|c|c|c|c|}
\hline Parameter & ACH 0 & ACH 1 & ACH 2 \\
\hline USRT of referential ACH [68] & 400 & 1320 & 1320 \\
\hline Specific cost of referential ACH (2016) $\left(\mathrm{USD}^{\mathrm{USRT}}{ }^{-1}\right)$ [68] & 2300 & 1800 & 1800 \\
\hline USRT of model ACH [63] & 375 & 1125 & 1350 \\
\hline Specific cost of model ACH (2016) (USD USRT ${ }^{-1}$ ) & 1841 & 1534 & 2156 \\
\hline Cost of model ACH (2016) (USD) & 808,594 & $1,725,852$ & $2,485,227$ \\
\hline Exchange rate (USD EUR ${ }^{-1}$ ) [70] & & 0.83 & \\
\hline CEPCI index (2016) [71] & & 541.7 & \\
\hline CEPCI index (2020) [72] & & 668.0 & \\
\hline Cost of model ACH (2020) (EUR) & 827,610 & $1,766,442$ & $2,543,676$ \\
\hline Total cost of ACH (2020) (EUR) & & $5,150,000$ & \\
\hline
\end{tabular}

Investment cost of heat exchangers (additional coolers) E0, E6, E8, E10, and E12 was estimated by available cost curve dependent on the heat transfer area obtained from available literature [73]. Therefore, approximative heat transfer areas of additional model heat exchangers were estimated by solving the overall heat transfer Equation (4).

$$
\dot{Q}=U A \Delta T_{l s}
$$

where $\mathrm{U}$ is the overall heat transfer coefficient, which is the function of fluid properties, material composition of the heat exchanger and the flow geometry with the estimated value of $100 \mathrm{~W} / \mathrm{m}^{2} / \mathrm{K}$ [74]; $\Delta T_{l s}$ is the log-mean temperature difference calculated by Equation (5), where $t_{a i r, \text { in }}, t_{a i r, o u t}$ are inlet and outlet temperatures of air and $t_{w, \text { in }}, t_{w, \text { out }}$ are inlet and outlet temperatures of water.

$$
\Delta T_{l s}=\frac{\left(t_{\text {air, in }}-t_{w, \text { out }}\right)-\left(t_{\text {air }, \text { out }}-t_{w, \text { in }}\right)}{\ln \frac{\left(t_{\text {air, }, \text { n }}-t_{w, \text { out }}\right)}{\left(t_{\text {air }, \text { out }}-t_{w, \text { in }}\right)}}
$$

Since the heat exchanger duty, $Q$, is a known parameter, the only unknown parameter in Equation (5) is the heat transfer area. Final values of heat transfer area and cost of heat exchangers are provided in Table 2.

\begin{tabular}{|c|c|c|c|c|c|}
\hline Heat Exchanger/Parameter & E0 & E6 & E8 & E10 & E12 \\
\hline$\dot{Q}(\mathrm{MW})$ & 1336.2 & 6392.5 & 5190.8 & 5327.4 & 4324.9 \\
\hline$U\left(\widetilde{\mathrm{W}} \mathrm{m}^{-2} \mathrm{~K}^{-1}\right)$ & & & 100 & & \\
\hline$\Delta T\left({ }^{\circ} \mathrm{C}\right)$ & 9.8 & 30.9 & 16.0 & 45.8 & 15.3 \\
\hline$A\left(\mathrm{~m}^{2}\right)$ & 1362.4 & 2068.4 & 3242.9 & 1164.3 & 2826.1 \\
\hline$A$ with margin $\left(\mathrm{m}^{2}\right)$ & 1500 & 2500 & 3500 & 1500 & 3000 \\
\hline Cost (1998) (USD) [73] & 25,000 & 40,000 & 50,000 & 25,000 & 45,000 \\
\hline Exchange rate (USD EUR ${ }^{-1}$ ) [70] & & & 0.83 & & \\
\hline CEPCI index (1998) [75] & & & 389.5 & & \\
\hline CEPCI index (2020) [72] & & & 668.0 & & \\
\hline Cost (2020) (EUR) & 35,586 & 56,938 & 71,113 & 35,586 & 64,056 \\
\hline Total investment cost (EUR) & & & 264,000 & & \\
\hline
\end{tabular}

Table 2. Estimation of heat exchangers investment costs.

Total estimated purchased cost of ACH and heat exchangers is EUR 5.41 mil. To calculate total investment cost, direct and indirect costs had to be added [76]. Total investment cost after adding direct and indirect cost to the purchase cost of process equipment 
is shown in Table 3, following the cost engineering guidelines in Peters et al. [69]. The resulting total investment cost to key equipment cost of 3.83 is somewhat lower than the typical values of 4 to 6 reported in [69] due to the proposed technology change and the already available infrastructure and is thus somewhat lower than an analogous green field investment. No operating costs other than electric energy consumption for $\mathrm{ACH}$ auxiliaries (pumps, fans, etc.), based on vendor documentation [63] were considered.

Table 3. Total investment cost estimation [69].

\begin{tabular}{cccc}
\hline \multicolumn{2}{c}{ Purchase Cost of Equipment (EUR mil.) } & \multicolumn{2}{c}{$\mathbf{5 . 4 1}(\mathbf{1 0 0} \%)$} \\
\hline \multicolumn{2}{c}{ Direct Cost } & \multicolumn{2}{c}{ Indirect Cost } \\
\hline Installation of equipment & $40 \%$ & Projecting and control & $33 \%$ \\
Measurement and regulation & $35 \%$ & Building costs & $20 \%$ \\
Pipes & $70 \%$ & Legalization costs & $4 \%$ \\
Land consolidation & $10 \%$ & Payments to & $20 \%$ \\
Services & $10 \%$ & contractors & $30 \%$ \\
& \multicolumn{2}{c}{ Reserves } \\
\hline Total direct and indirect costs & Circulating capital \\
\hline Total investment costs (EUR mil.) & $282 \%$ \\
\hline
\end{tabular}

\subsection{Model Industrial Thermal Power Plant}

An industrial thermal Clausius-Rankine power plant model was set up (Appendix C, Figure A2), mirroring a real plant operating in SLOVNAFT refinery [77].

Automated monitoring system (AMS) outputs in forms of yearly reports are available on SLOVNAFT websites: [78]: years 2012-2016 and [79]: year 2018, comprising the amounts of produced greenhouse gas emissions and particulate matter in the industrial thermal power plant as well as in refinery's production units. An excerpt of these data is provided in Table 4.

Table 4. Selected data on greenhouse gas emissions from thermal power plant based on [78,79].

\begin{tabular}{cccccc}
\hline \multirow{2}{*}{ Emissions (t) } & \multicolumn{5}{c}{ Year (Days of Validated AMS Operation and Data Recording) } \\
\cline { 2 - 5 } & $\mathbf{2 0 1 3} \mathbf{( 2 4 9 )}$ & $\mathbf{2 0 1 4} \mathbf{( 2 4 2 )}$ & $\mathbf{2 0 1 5} \mathbf{( 7 2 )}$ & $\mathbf{2 0 1 6} \mathbf{( 3 1 6 )}$ & $\mathbf{2 0 1 8}$ (Not Provided) \\
\hline $\mathrm{CO}_{2}$ & 318,256 & 347,916 & 128,889 & 517,115 & 776,743 \\
$\mathrm{CO}$ & 4.108 & 12.696 & 1.311 & 2.828 & 10.278 \\
$\mathrm{NO}_{\mathbf{x}}$ & 336.851 & 393.087 & 126.009 & 531.929 & 1165.025 \\
$\mathrm{SO}_{\mathbf{x}}$ & 142.791 & 226.096 & 74.696 & 444.756 & 705.554 \\
\hline
\end{tabular}

The given data were used to calculate specific emissions of carbon monoxide, nitrogen oxides, and sulfur oxides per one ton of emitted carbon dioxide and the values are shown in Table 5. A reasonable value of carbon dioxide produced per unit of fuel combusted can obtained from fuel combustion stoichiometry. Thus, data in Table 5 served to calculate greenhouse gases' (other than $\mathrm{CO}_{2}$ ) emission from a model industrial thermal power plant.

Table 5. Average specific emissions of pollutants in grams per ton of produced $\mathrm{CO}_{2}$.

\begin{tabular}{cc}
\hline Pollutant & Average Specific Emissions in Grams per Ton of Produced $\mathbf{C O}_{2}$ \\
\hline $\mathrm{CO}$ & 15.1 \\
$\mathrm{NO}_{\mathrm{x}}$ & 1222 \\
$\mathrm{SO}_{\mathrm{x}}$ & 763 \\
\hline
\end{tabular}




\section{Results and Discussion}

\subsection{ASU Model Verification}

Key results of mathematical model verification and comparison with model design simulation data are presented in Appendix D, Tables A9-A11.

Verification of the developed mathematical model via simulation show very good correspondence with data of the selected basic model [36], with key variables values differences below $1 \%$. The required quality and quantity of product streams are achieved. For further modifications and simulations, model parameters in the cryogenic section are kept the same.

\subsection{Results of ASU Design and Operation Improvement by Absorption Cooling}

\subsubsection{Exploitation of Internal Waste Heat for Cold Production}

Key simulation results of the compression section process equipment obtained from the mathematical model including absorption coolers exploiting internal waste heat and their comparison with results obtained from a basic mathematical model are presented in Tables $6-10$.

Table 6. Comparison of key parameters related to compressor K2 obtained by basic ASU model and by model comprising $\mathrm{ACH}$.

\begin{tabular}{|c|c|c|c|c|c|c|}
\hline \multicolumn{7}{|c|}{ Compressor $\mathrm{K} 2$} \\
\hline & \multicolumn{3}{|c|}{ Model with ACH } & \multicolumn{3}{|c|}{ Basic Mathematical Model } \\
\hline Stream & $\mathrm{m}\left(\mathrm{t} \mathrm{h}^{-1}\right)$ & $\mathrm{t}\left({ }^{\circ} \mathrm{C}\right)$ & $\mathrm{P}(\mathrm{kPa})$ & $\mathrm{m}\left(\mathrm{t} \mathrm{h}^{-1}\right)$ & $\mathrm{t}\left({ }^{\circ} \mathrm{C}\right)$ & $\mathrm{P}(\mathrm{kPa})$ \\
\hline S4 & 497.3 & 16.7 & 220 & 500 & 40.0 & 240 \\
\hline S6 & 497.3 & 156.9 & 630 & 500 & 168.9 & 600 \\
\hline $\begin{array}{l}\text { Power input } \\
\quad(\mathrm{kW})\end{array}$ & \multicolumn{3}{|c|}{19,620} & \multicolumn{3}{|c|}{18,252} \\
\hline
\end{tabular}

Table 7. Comparison of key parameters related to compressor K3 obtained by basic ASU model and by model comprising $\mathrm{ACH}$.

\begin{tabular}{ccccccc}
\hline \multicolumn{7}{c}{ Compressor K3 } \\
\hline Model with ACH & \multicolumn{3}{c}{ Basic Mathematical Model } \\
\hline Stream & $\mathrm{m}\left(\mathrm{t} \mathrm{h}^{-1}\right)$ & $\mathrm{t}\left({ }^{\circ} \mathrm{C}\right)$ & $\mathrm{P}(\mathrm{kPa})$ & $\mathrm{m}\left(\mathrm{t} \mathrm{h}^{-1}\right)$ & $\mathrm{t}\left({ }^{\circ} \mathrm{C}\right)$ & $\mathrm{P}(\mathrm{kPa})$ \\
\hline S14 & 158.7 & 16.2 & 600 & 159.5 & 40.0 & 590 \\
S16 & 158.7 & 44.2 & 760 & 159.5 & 70.7 & 750 \\
\hline $\begin{array}{c}\text { Power input } \\
(\mathrm{kW})\end{array}$ & & 1241 & & 1377 & \\
\hline
\end{tabular}

Table 8. Comparison of key parameters related to flash separators obtained by basic ASU model and by model comprising $\mathrm{ACH}$.

Flash Separators F1, F2, F3, F4

\begin{tabular}{ccccccc}
\hline & \multicolumn{3}{c}{ Model with ACH } & \multicolumn{3}{c}{ Basic Mathematical Model } \\
\hline Stream & ${\mathrm{m}\left(\mathrm{kg} \mathrm{h}^{-1}\right)} \mathrm{t}\left({ }^{\circ} \mathrm{C}\right)$ & $\mathrm{P}(\mathrm{kPa})$ & ${\mathrm{m}\left(\mathrm{kg} \mathrm{h}^{-1}\right)}^{\mathrm{t}\left({ }^{\circ} \mathrm{C}\right)}$ & $\mathrm{P}(\mathrm{kPa})$ \\
\hline S5 (F1) & 2694.1 & 16.7 & 220 & 0 & 40 & 240 \\
S15 (F2) & 443.8 & 16.2 & 600 & 244.4 & 40 & 590 \\
S11 (F3) & 943.6 & 16.2 & 600 & 519.2 & 40 & 590 \\
S19 (F4) & 0 & - & - & 252.2 & 40 & 740 \\
\hline
\end{tabular}


Table 9. Comparison of key parameters related to adsorber A1 obtained by basic ASU model and by model comprising $\mathrm{ACH}$. Qreg: power input for adsorber regeneration.

\begin{tabular}{|c|c|c|c|c|c|c|}
\hline \multicolumn{7}{|c|}{ Adsorber A1 } \\
\hline & \multicolumn{3}{|c|}{ Model with ACH } & \multicolumn{3}{|c|}{ Basic Mathematical Model } \\
\hline Stream & $\mathrm{m}\left(\mathrm{th}^{-1}\right)$ & $\mathrm{t}\left({ }^{\circ} \mathrm{C}\right)$ & $\mathrm{P}(\mathrm{kPa})$ & $\mathrm{m}\left(\mathrm{t} \mathrm{h}^{-1}\right)$ & $\mathrm{t}\left({ }^{\circ} \mathrm{C}\right)$ & $\mathrm{P}(\mathrm{kPa})$ \\
\hline S10 & 337.2 & 16.2 & 600 & 339 & 40 & 590 \\
\hline S12A & 336.5 & 20.9 & 590 & 336.5 & 60.5 & 580 \\
\hline $\mathrm{H}_{2} \mathrm{O}\left(\mathrm{kg} \mathrm{h}^{-1}\right)$ & \multicolumn{3}{|c|}{542.9} & \multicolumn{3}{|c|}{2498.4} \\
\hline Qreg $(\mathrm{kW})$ & \multicolumn{3}{|c|}{452.4} & \multicolumn{3}{|c|}{1952} \\
\hline
\end{tabular}

Table 10. Comparison of key parameters related to adsorber A2 obtained by basic ASU model and by model comprising $\mathrm{ACH}$.

\begin{tabular}{|c|c|c|c|c|c|c|}
\hline \multicolumn{7}{|c|}{ Adsorber A2 } \\
\hline & \multicolumn{3}{|c|}{ Model with ACH } & \multicolumn{3}{|c|}{ Basic Mathematical Model } \\
\hline Stream & $\mathrm{m}\left(\mathrm{t} \mathrm{h}^{-1}\right)$ & $\mathrm{t}\left({ }^{\circ} \mathrm{C}\right)$ & $\mathrm{P}(\mathrm{kPa})$ & $\mathrm{m}\left(\mathrm{t} \mathrm{h}^{-1}\right)$ & $\mathrm{t}\left({ }^{\circ} \mathrm{C}\right)$ & $\mathrm{P}(\mathrm{kPa})$ \\
\hline S10 & 158.6 & 35.0 & 750 & 159.3 & 40.0 & 740 \\
\hline S12A & 158.4 & 39.7 & 740 & 158.4 & 56.5 & 730 \\
\hline $\mathrm{H}_{2} \mathrm{O}\left(\mathrm{kg} \mathrm{h}^{-1}\right)$ & \multicolumn{3}{|c|}{255.1} & \multicolumn{3}{|c|}{886.6} \\
\hline$Q_{\text {reg }}(\mathrm{kW})$ & \multicolumn{3}{|c|}{212.6} & \multicolumn{3}{|c|}{738.8} \\
\hline
\end{tabular}

Compression ratio and mass flow of compressed air are affected by $\mathrm{ACH}$ implementation both in compressor K2 (Table 6) and compressor K3 (Table 7). As for compressor K2, the increase in the compression ratio overweighs the effect of a slight air mass flow decrease as well as that of decreased inlet air temperature, which results in an almost $1.5 \mathrm{MW}$ power consumption increase $(+7.5 \%)$. In compressor $\mathrm{K} 3$, the compression ratio, compressed air mass flow, as well as inlet air temperature decrease after $\mathrm{ACH}$ implementation, leading to an almost $10 \%$ decrease in its power consumption. However, since its nominal power input is lower than $10 \%$ of that of compressor K2, the overall effect on power consumption for air compression in all compressors together is negative.

The change in compressed air mass flow after ACH implementation is documented in Tables 8-10 showing the redistribution of water vapor removal from air. While water vapor predominantly passes through the compression section and is removed in absorbers in the base case, its large portion is removed already in the compression section after $\mathrm{ACH}$ implementation (around 4 of total $5 \mathrm{th}^{-1}$, see Table 8) due to absorption cooling to a significantly lower temperature, thus a large share of water vapor is condensed and removed in separators F1 to F3. As shown in Tables 9 and 10, larger adsorber load caused by much higher water adsorption rate in both adsorbers in the base case led to a substantially higher power consumption for their regeneration, with a calculated difference of almost $+2 \mathrm{MW}$ in case of A1 and of over 0.5 MW in case of A2. Therefore, implementation of $\mathrm{ACHs}$ results in an increased compressor load while that needed for adsorbers regeneration is cut down. Air pressure losses have a more significant impact on compression power consumption than the decreased inlet air temperature achieved by $\mathrm{ACH}$ implementation. Thus, air pressure loss in heat exchangers is the most important parameter, crucial to energy feasibility of ACH implementation. Air humidity effect on the power consumption for adsorbers regeneration, etc., has a profound impact on achievable energy savings. Thus, both parameters are examined in detail later.

All modeled cooling towers operate with the same model parameters. Results of representative cooling tower $\mathrm{C} 1$ simulation are presented in Appendix E, Table A12. Implementation of cooling towers into the developed mathematical model ensures the required 
inlet process temperature of cooling water to be achieved. Further adjustments of cooling tower model parameters are not needed.

\subsubsection{Exploitation of External Waste Heat for Cold Production}

The key results of this analysis are the results of the compressor $\mathrm{K} 1$ simulation, which are presented in Table 11.

Table 11. Comparison of key parameters related to compressor $\mathrm{K} 1$ obtained by basic ASU model and by model comprising $\mathrm{ACH}$.

\begin{tabular}{ccccccc}
\hline \multicolumn{7}{c}{ Compressor K1 } \\
\hline Model with ACH & \multicolumn{3}{c}{ Basic Mathematical Model } \\
\hline Stream & $\mathrm{m}\left(\mathrm{t} \mathrm{h}^{-1}\right)$ & $\mathrm{t}\left({ }^{\circ} \mathrm{C}\right)$ & $\mathrm{P}(\mathrm{kPa})$ & $\mathrm{m}\left(\mathrm{t} \mathrm{h}^{-1}\right)$ & $\mathrm{t}\left({ }^{\circ} \mathrm{C}\right)$ & $\mathrm{P}(\mathrm{kPa})$ \\
\hline $\mathrm{S} 1$ & 500 & 15.5 & 90 & 500 & 25.0 & 100 \\
$\mathrm{~S} 2$ & 500 & 159.2 & 250 & 500 & 147.9 & 250 \\
\hline $\begin{array}{c}\text { Power input } \\
(\mathrm{kW})\end{array}$ & & 20,297 & & 17,381 \\
\hline
\end{tabular}

Similarly, as in the model of ASU with ACH utilizing its own waste heat from the compression section, compressed air pressure loss in the modeled heat exchangers causes a significant increase in compressor power consumption although the inlet air temperature decreases by $10{ }^{\circ} \mathrm{C}$. Results show that the proposed compression section improvements are infeasible at the model parameters assumed.

\subsection{Impact of Air Pressure Loss in Heat Exhangers}

Model parameter-air pressure loss (10 kPa)—specified in all modeled heat exchangers causes significant pressure loss in the compression section, which has to be compensated by increasing the compression ratio in compressors, thus leading to significant compression work increase. Based on available technical documentation for real air-water coolers [80], the approximate real value of compressed air pressure loss in water coolers is a fraction of the inlet air pressure rather than a constant value.

Thus, three representative situations are evaluated. The pressure loss of compressed air in all modeled heat exchangers is specified to be 0,1 , and $2 \%$ of inlet air pressure. Modification of the air pressure loss model parameter is performed for both the modified and basic mathematical model and the effect of air pressure loss on compression energy consumption is assessed by comparing the results of these mathematical models. The main monitored parameters include compressor power input and compression ratio. Results of models considering 1 and $2 \%$ air pressure loss in heat exchangers are shown in Table 12. This case study confirms the significant effect of air pressure loss on compression work. The electrical power input savings for models with zero pressure loss in all modeled heat exchangers equals approximately 2.18 MW. Table 12 shows that air pressure loss in heat exchangers of $2 \%$ of inlet air pressure results in only negligible electrical power savings for compression. With each air pressure loss decrease by $1 \%$, the value of annual electrical power savings in the compression section increases by $9500 \mathrm{MWh}$. 
Table 12. Key model parameters sensitivity to air pressure loss in heat exchangers. $\Delta$ : Difference.

\begin{tabular}{|c|c|c|c|c|}
\hline \multirow{2}{*}{$\begin{array}{c}\text { Air Pressure Loss } \\
\text { Compressor }\end{array}$} & \multicolumn{2}{|c|}{$2 \%$} & \multicolumn{2}{|c|}{$1 \%$} \\
\hline & $\begin{array}{l}\text { Model without ACH } \\
\text { (MW) }\end{array}$ & $\begin{array}{c}\text { Model with ACH } \\
\text { (MW) }\end{array}$ & $\begin{array}{l}\text { Model without ACH } \\
\text { (MW) }\end{array}$ & $\begin{array}{c}\text { Model with ACH } \\
\text { (MW) }\end{array}$ \\
\hline K1 & 17.38 & 17.26 & 17.38 & 17.05 \\
\hline K2 & 18.23 & 18.46 & 17.78 & 17.13 \\
\hline K3 & 1.394 & 1.273 & 1.339 & 1.222 \\
\hline$\Delta$ power $\mathrm{K} 1(\mathrm{MW})$ & \multicolumn{2}{|c|}{0.120} & \multicolumn{2}{|c|}{0.33} \\
\hline$\Delta$ power K2 (MW) & \multicolumn{2}{|c|}{-0.230} & \multicolumn{2}{|c|}{0.65} \\
\hline$\Delta$ power K3 $(\mathrm{MW})$ & \multicolumn{2}{|c|}{0.121} & \multicolumn{2}{|c|}{0.117} \\
\hline $\begin{array}{l}\text { Total power savings } \\
(\mathrm{MW} ; \%)\end{array}$ & \multicolumn{2}{|c|}{ 0.011; negligible } & \multicolumn{2}{|c|}{$1.097 ; 3.0$} \\
\hline
\end{tabular}

\subsection{Impact of Variable Ambient Air Humidity}

The results of annual electrical power savings calculation for adsorber regeneration based on Equation (1) and constant ambient air properties assumed in [36] are provided in Appendix E, Table A13. The calculated total annual electrical power savings value is valid only for one model situation - constant value of air humidity during the year. Since air humidity is a variable parameter and its value depends on weather, season, location and other parameters, annual electrical power savings shown in Table A13 has to be recalculated employing ambient air properties dataset for Košice-Center location.

In the model including absorption coolers, calculated value of air humidity in the inlet of adsorbers equals to $1.54 \mathrm{~g} \mathrm{~kg}^{-1}$ of dry air. In case of higher air humidity values, excess water in compressed air condenses in the compression section before entering the adsorbers and the inlet air humidity value does not change. As it results from Figures 4-6, an air humidity value of $1.54 \mathrm{~g} \mathrm{~kg}^{-1}$ and lower occurs only very infrequently. Therefore, a constant value of electrical power input for adsorber regeneration can be assumed in this model.

In the model without absorption coolers, calculated values of air humidity at the inlet of adsorbers A1 $\left(6.48 \mathrm{~g} \mathrm{~kg}^{-1}\right)$ and A2 $\left(5.63 \mathrm{~g} \mathrm{~kg}^{-1}\right)$ are significantly higher than in the model with absorption coolers. Figure 7 shows that in case of higher air humidity values, excess water condenses in the compression section. However, air humidity values below the mentioned values $\left(6.48\right.$ and $5.63 \mathrm{~g} \mathrm{~kg}^{-1}$ ) results in smaller amount of water adsorbed and, subsequently, in lower power consumption for adsorbers regeneration. This is apparent from Figure $7 \mathrm{a}, \mathrm{b}$ showing the calculated water removal by compressed air intercooling and by adsorption and distribution. Its impact on the required power input for adsorber regeneration can also be observed increasing linearly with air humidity up to $5.63 \mathrm{~g} \mathrm{~kg}^{-1}$, which represents saturated air at the inlet of adsorber A2. With still increasing air humidity, power consumption for adsorber $\mathrm{A} 2$ regeneration does not change any more, as the air at its inlet is already saturated and excess water vapor is removed in the compression section, while that for A1 further increases. As the power consumption for A1 regeneration is much higher than that for A2, total power consumption increase for regeneration decreases only slightly. After reaching air humidity of $6.48 \mathrm{~g} \mathrm{~kg}^{-1}$, saturated air conditions are achieved at adsorber A1 inlet, i.e., maximal adsorber load accompanied by maximal power consumption for the regeneration of both adsorbers are reached and do not change with further air humidity increase as excess water vapor is condensed in the compression section. 
(a) - Condensed - Adsorber A1 - Adsorber A2 - Power input

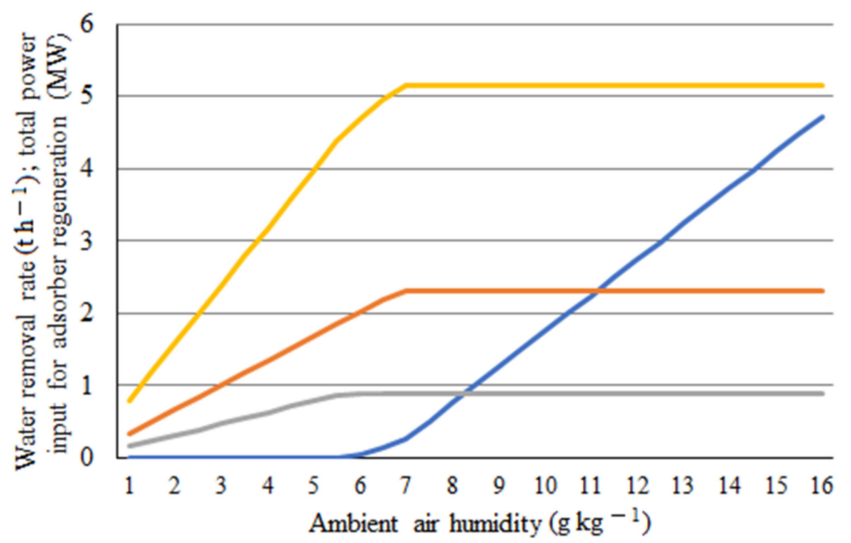

(b) - Condensed -Adsorber 1 -Adsorber 2

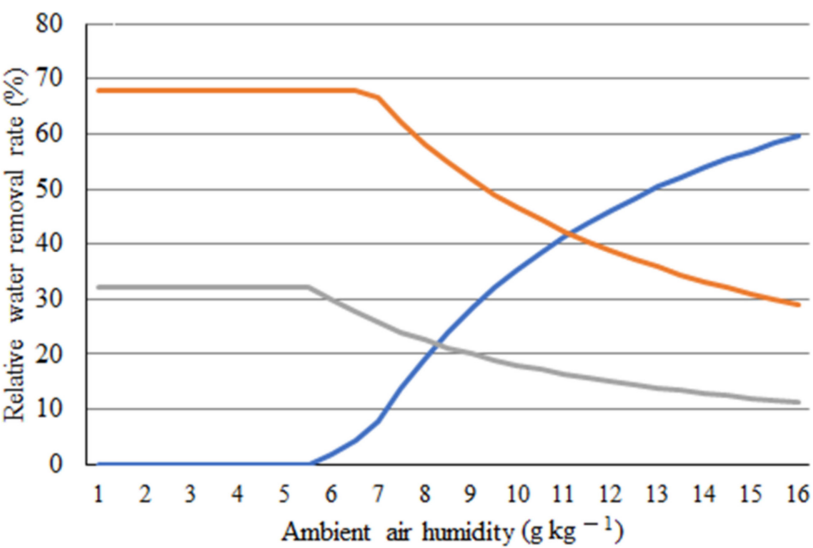

Figure 7. $(\mathbf{a}, \mathbf{b})$ Water removal rate and total power input for adsorber regeneration (a) and water removal rate distribution (b) as a function of ambient air humidity for model without absorption coolers. Condensed = water condensed in compression section intercoolers and coolers; Adsorber A1 = water removed in adsorber A1; Adsorber A2 = water removed in adsorber A2.

By processing the ambient air dataset, percentages of time during 2020 with air humidity values lower and higher than 6.48 and $5.63 \mathrm{~g} \mathrm{~kg}^{-1}$, respectively, are estimated. Moreover, the average air humidity is calculated for the fraction of the year with lower air humidity. This value is subsequently used to calculate a new average electrical power input for adsorber regeneration in the model without absorption coolers, as presented in Appendix E, Table A14.

The final value of recalculated annual electrical power savings for adsorber regeneration is presented in Table 13 and it is used for further calculations related to economical assessment. Compared to the value of electrical power savings presented in Table A13, the recalculated value of electrical power savings for model location Košice-Center is by $10,570 \mathrm{MWh}$ lower. Nevertheless, compared to the annual power consumption of all three compressors together plus power input for adsorbers regeneration, amounting to $353 \mathrm{GWh}$ per year, the achievable power consumption reduction is $6.7 \%$.

Table 13. Recalculated power input savings in model with ACH compared to basic model (without ACH).

\begin{tabular}{ccc}
\hline Parameter & A1 & A2 \\
\hline Recalculated electrical power input for adsorber regeneration (model without ACH) (MW) & 2.767 & 1.167 \\
Electrical power input for adsorber regeneration (model with ACH) (MW) & 0.836 & 0.393 \\
Recalculated electrical power input savings (MW) & 1.931 & 0.773 \\
Recalculated annual (8760 h per year) electrical power savings for adsorber regeneration (MWh) & 16,916 & 6775 \\
\hline Total recalculated annual electrical power savings for adsorbers regeneration (MWh) & 23,691 \\
\hline
\end{tabular}

\subsection{Economic Parameters}

Feasibility of the proposed investment-implementation of absorption coolers and additional heat exchangers to the basic cryogenic air separation model-is evaluated through a simple payback period (SPBP) using Equation (6).

$$
\text { SPBP }=\frac{\text { Total investment cost }}{\text { Annual cash flow }}
$$

Total investment cost (EUR 20.7 mil) is estimated in part 2.6 Economic Calculations. Annual cash flow results from electrical power savings for compressors operation and for adsorbers regeneration. 
Power input savings for compressors K1, K2, and K3 depend on the percentage of air pressure loss in the modeled heat exchangers; final savings are presented in Table 14. Annual power consumption for $\mathrm{ACH}$ pumps is subtracted from the total annual electrical power savings obtained from available technical documentation for a real $\mathrm{ACH}$ [63].

Table 14. Total annual power savings calculation resulting from $\mathrm{ACH}$ implementation.

\begin{tabular}{cccc}
\hline \% of Air Pressure Loss & $\mathbf{2 \%}$ & $\mathbf{1 \%}$ & $\mathbf{0 \%}$ \\
\hline Electrical power input savings for compression (MW) & 0.011 & 1.097 & 2.183 \\
Annual electrical power savings for compression (MWh) & 96.4 & 9609.7 & $19,123.1$ \\
Annual electrical power savings for adsorber regeneration (MWh) & & 23,691 & -200 \\
Annual electrical power consumption for ACH pumps (MWh) & & 33,101 & 42,614 \\
\hline Total annual power savings (MWh) & 23,588 & & \\
\hline
\end{tabular}

Results in Table 14 indicate significant influence of varying air pressure loss in the modeled heat exchangers on electrical power savings. Under theoretical conditions-zero air pressure loss-the highest electrical power savings can be achieved. With each air pressure loss increase by $1 \%$, the electrical power savings value is reduced by $9500 \mathrm{MWh}$ per year. Annual cash flow is obtained by multiplying the total annual power savings in Table 14 by the cost of electricity assumed in the range of EUR $50-100 / \mathrm{MWh}^{-1}$. Results of the sensitivity analysis are provided in Figure 8. As can be seen, simple payback period values vary from 4 to 18 years, with both air pressure loss and electricity price being important.

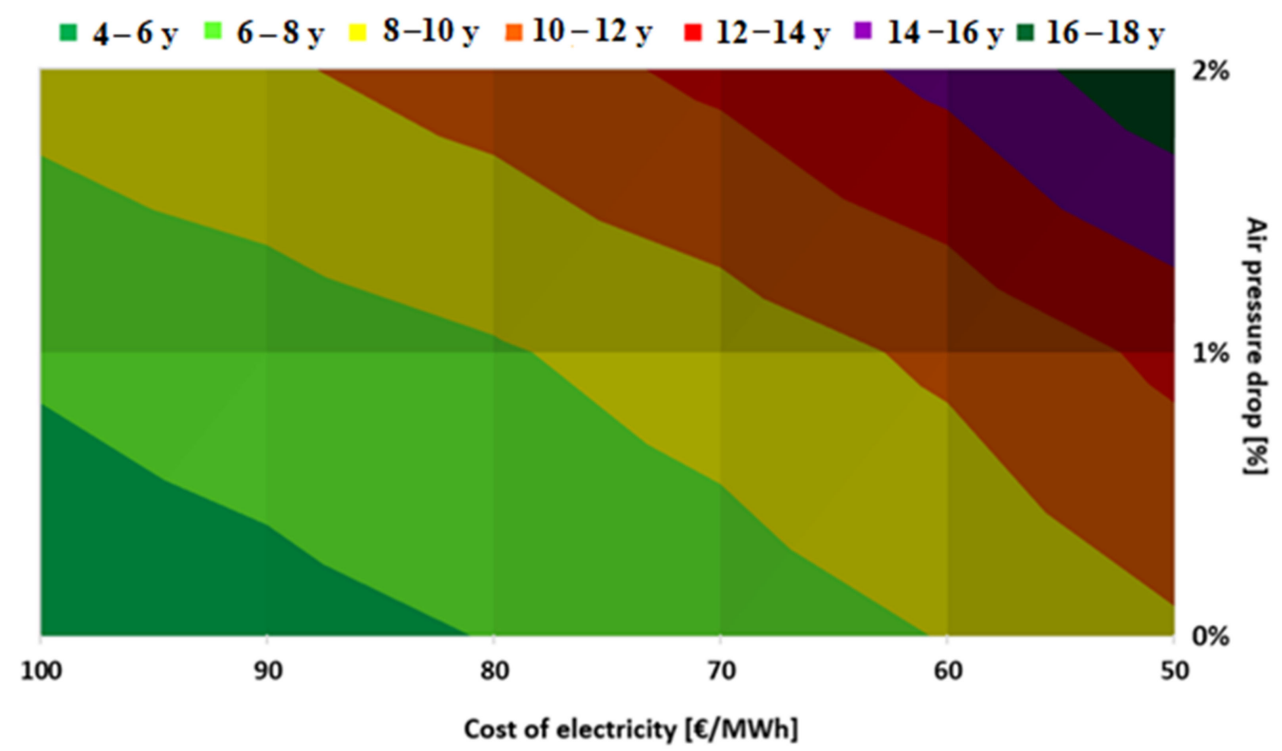

Figure 8. Simple payback period values in years as a function of electricity price and air pressure loss.

It should, however, be remembered that the price of carbon dioxide emissions increased rapidly over the last two years, currently exceeding EUR $55 \mathrm{t}^{-1}$ [81] and it is expected to reach EUR $150 \mathrm{t}^{-1}$ until 2050 [52], which is partly reflected in the currently growing electricity prices. Continuation of this trend significantly increases the economic feasibility of the proposed ASU performance improvement and reduces the simple payback period to 5 years even in case of a $2 \%$ air pressure loss in the heat exchangers. Simple recalculation of the above figures yields achievable reduction of specific oxygen production cost of EUR 2-4.2 $\mathrm{t}^{-1}$ which represents 3 to $5 \%$ of typical oxygen production cost [30]. 


\subsection{Achievable Reduction of Greenhouse Gas Emissions}

The following thermal power plant parameters are obtained, expressed per $1 \mathrm{MWh}$ of net produced electricity: steam production in steam boiler: $4.537 \mathrm{t}$; fuel consumption: $0.2904 \mathrm{t}$; $\mathrm{CO}_{2}$ emissions: $0.926 \mathrm{t}$. The resulting net power production efficiency of $30.6 \%$ is somewhat lower than efficiencies of up to $40(45) \%$ reached in large power plants [82] because of the conservative design and parameters of the considered plant with lower live steam parameters, lower number of boiler feedwater heaters, and absence of steam reheating. Variny et al. [83] reported a value of specific net power production of $3 \mathrm{MWh}$ per 1 ton of combusted fuel in an industrial steam power plant, which agrees well with the obtained specific fuel consumption of $0.2904 \mathrm{t}$ per $1 \mathrm{MWh}$ of net power production (3.44 MWh per ton of fuel).

The obtained specific $\mathrm{CO}_{2}$ emissions of slightly over $0.9 \mathrm{t} \mathrm{MWh}^{-1}$ are comparable with those from $>100 \mathrm{MW}$ range subcritical coal-fired power plants [84], or oxyfuel power plants [39] with the lower net power production efficiency impact somewhat counterbalanced by lower carbon content in fuel compared to common coal. $\mathrm{SO}_{\mathrm{x}}$ and $\mathrm{NO}_{\mathrm{x}}$ emissions listed in Table 5 can be recalculated to values per MWh of net produced electricity, yielding $0.707 \mathrm{~kg} \mathrm{MWh}^{-1}$ for $\mathrm{SO}_{\mathrm{x}}$ and $1.132 \mathrm{~kg} \mathrm{MWh}^{-1}$ for $\mathrm{NO}_{\mathrm{x}}$, respectively. They are significantly higher than values reported by Campbell et al. [84] for a large coal-fired power plant, reaching $0.2 \mathrm{~kg} \mathrm{MWh}^{-1}$ for $\mathrm{SO}_{\mathrm{x}}$ and $0.472 \mathrm{~kg} \mathrm{MWh}^{-1}$ for $\mathrm{NO}_{\mathrm{x}}$, respectively. However, Strachan and Farrell [85] listed specific emissions of greenhouse gases from various power production technologies, including a coal-fired power plant with three- to five-fold higher values for both $\mathrm{SO}_{\mathrm{x}}$ and $\mathrm{NO}_{\mathrm{x}}$ than those obtained in this study, while the corresponding $\mathrm{CO}_{2}$ emission factor of $0.965 \mathrm{t} \mathrm{MWh}^{-1}$ presented almost equals with that calculated in this study. Table 15 shows a comparison of the $\mathrm{CO}_{2}$ emission factors reported in further relevant literature and the resulting achievable cut in annual $\mathrm{CO}_{2}$ emissions. In a similar manner, Table 16 lists the expected $\mathrm{NO}_{\mathrm{x}}$ and $\mathrm{SO}_{\mathrm{x}}$ emissions decrease. For comparison, both Tables 15 and 16 contain emission factors representing an energy mix of Slovenské elektrárne, a.s., the major electric energy producer in Slovak Republic, adopted from [83]. Slovenské elektrárne, a.s. produce a large share of electricity in nuclear plants and hydro power plants and are thus considered an environmentally friendly electricity producer.

Emission factors for $\mathrm{CO}_{2}$ reported in various studies and calculated in this study range between 0.7 to over $0.9 \mathrm{t} \mathrm{MWh}^{-1}$, so the expected cut in its emissions is between 23 to 31 kilotons per year and between 16 to 22 kilotons per year for 1 and $2 \%$ air pressure loss in the heat exchangers, respectively. Thus, the uncertainty regarding the pressure loss value in the heat exchangers has a comparable effect on $\mathrm{CO}_{2}$ emissions' reduction as the fossil fuel-based emission factor variability. If a more environmentally friendly energy mix is considered, $\mathrm{CO}_{2}$ emission reduction due to $\mathrm{ACH}$ implementation can be reduced by around $80 \%$. This is in line with the general understanding that increased share of renewables in the consumed electric energy reduces the environmental benefit of its consumption reduction.

Table 15. Decrease in annual emissions of $\mathrm{CO}_{2}$ resulting from $\mathrm{ACH}$ implementation.

\begin{tabular}{|c|c|c|c|c|c|c|}
\hline Study/Value & This Study & [86] & [54] & [57] & [31] & [83] \\
\hline Fuel & $\mathrm{HFO}$ & Heating oil & Heavy oil & Heavy oil & Coal & Energy mix \\
\hline $\begin{array}{l}\text { Emission factor } \\
\left(\mathrm{t} \mathrm{MWh}^{-1}\right)\end{array}$ & 0.926 & $\begin{array}{l}0.778 \\
(\min .0 .731, \\
\max .0 .857)\end{array}$ & 0.72 & $\begin{array}{l}0.802 \text { old plant; } \\
0.702 \text { new plant }\end{array}$ & $\begin{array}{c}0.86 \text { conventional plant; } \\
0.743 \text { ultra-supercritical plant }\end{array}$ & 0.136 \\
\hline $\begin{array}{c}\text { Annual } \mathrm{CO}_{2} \text { emissions } \\
\text { decrease (Table 14, air } \\
\text { pressure loss } 1 \% \text { ) }(\mathrm{t})\end{array}$ & 30,652 & $\begin{array}{c}24,197 \text { to } \\
28,368\end{array}$ & 23,833 & $\begin{array}{l}23,237 \text { to } \\
26,574\end{array}$ & $\begin{array}{l}24,594 \text { to } \\
28,467\end{array}$ & 4502 \\
\hline $\begin{array}{c}\text { Annual } \mathrm{CO}_{2} \text { emissions } \\
\text { decrease (Table 14, air } \\
\text { pressure loss } 2 \% \text { ) }(\mathrm{t})\end{array}$ & 21,842 & 17,243 to 20,215 & 16,983 & 16,559 to 18,918 & 17,526 to 20,286 & 3208 \\
\hline
\end{tabular}


Table 16. Decrease in annual emissions of other major gaseous pollutants resulting from ACH implementation.

\begin{tabular}{|c|c|c|c|c|c|c|c|c|c|c|c|}
\hline \multirow{2}{*}{$\begin{array}{c}\text { Study/Value } \\
\text { Pollutant }\end{array}$} & \multicolumn{3}{|c|}{ This Study } & \multicolumn{2}{|c|}{$\begin{array}{l}\text { Campbell et al. [84] } \\
\text { (Coal Power Plant) }\end{array}$} & \multicolumn{3}{|c|}{$\begin{array}{l}\text { Strachan and Farrell [85] } \\
\text { (Coal Power Plant) }\end{array}$} & \multicolumn{3}{|c|}{$\begin{array}{c}\text { Variny et al. [83] (Electric Energy Mix of } \\
\text { Slovenské Elektrárne, a.s.) }\end{array}$} \\
\hline & $\mathrm{CO}$ & $\mathrm{SO}_{\mathrm{x}}$ & $\mathrm{NO}_{\mathbf{x}}$ & $\mathrm{CO}$ & $\mathrm{SO}_{\mathrm{x}}$ & $\mathrm{NO}_{\mathbf{x}}$ & $\mathrm{SO}_{\mathrm{x}}$ & $\mathrm{NO}_{\mathbf{x}}$ & $\mathrm{CO}$ & $\mathrm{SO}_{\mathrm{x}}$ & $\mathrm{NO}_{\mathbf{x}}$ \\
\hline $\begin{array}{l}\text { Emission factor } \\
\left(\mathrm{kg} \mathrm{MWh}^{-1}\right)\end{array}$ & 0.014 & 0.707 & 1.132 & 0.07 & 5.64 & 1.7 & 0.2 & 0.459 & 0.061 & 0.392 & 0.107 \\
\hline $\begin{array}{l}\text { Annual emissions } \\
\text { decrease (Table 14, air } \\
\text { pressure loss 1\%) (t) }\end{array}$ & 0.5 & 23.4 & 37.5 & 2.3 & 186.7 & 56.3 & 6.6 & 15.2 & 2.0 & 13.0 & 3.5 \\
\hline $\begin{array}{l}\text { Annual emissions } \\
\text { decrease (Table 14, air } \\
\text { pressure loss } 2 \% \text { ) (t) }\end{array}$ & 0.3 & 16.7 & 26.7 & 1.7 & 133.0 & 40.1 & 4.7 & 10.8 & 1.4 & 9.2 & 2.5 \\
\hline
\end{tabular}


However, as it results from Table 16, there is a much wider variability in $\mathrm{NO}_{\mathrm{x}}$ and $\mathrm{SO}_{\mathrm{x}}$ emission factors yielding a very wide range of possible emission reduction of these pollutants as $\mathrm{CO}_{2}$ emissions depend on fuel composition solely (if complete combustion can be assumed) while those of $\mathrm{CO}, \mathrm{NO}_{x}$, and $\mathrm{SO}_{\mathrm{x}}$ depend also on process conditions and parameters [87] and on the way how (and if) flue gas is cleaned before being emitted to the atmosphere [88]. Implementation of emission factors from energy mix [83] increases the range of possible emission reduction further, especially in case on $\mathrm{NO}_{\mathrm{x}}$ emissions where it amounts to almost $80 \%$. In case of $\mathrm{SO}_{\mathrm{x}}$, a further reduction of the annually released amount of around 50\% (9.2 vs. 16.7 tons per annum) can be seen in Table 16. The effect of air pressure loss in the heat exchangers on the resulting emissions' reduction is almost negligible in comparison.

From a quantitative point of view, it can be concluded that the achievable annual power consumption cut in the considered air separation units between 23 to $33 \mathrm{GWh}$ (6.7 to $9.4 \%$ ) translated into annual $\mathrm{CO}_{2}$ emissions' reduction by 16 to 31 kilotons and reduction of annual emissions of other major gaseous pollutants by up to 187 tons.

\section{Conclusions}

The present study provides a complex economic-energetic-environmental assessment of a model cryogenic ASU design's improvement by air pre-cooling and intercooling, using absorption coolers powered by waste heat from the compression section. Air humidity and air pressure loss in heat exchangers were identified as two key factors affecting energy consumption reduction when absorption coolers are implemented. Hourly variations of ambient air humidity were considered and water vapor removal distribution in the compression section and air dryers for the location Košice (Central Europe) was assessed, resulting in a realistic estimate of the corresponding power consumption for air dryer regeneration.

Achievable power savings of 6.7 to $9.4 \%$ are consistent with those presented in similar recent studies. For a model ASU processing $500 \mathrm{t} \mathrm{h}^{-1}$ of ambient air, power savings amounted to 23 to $33 \mathrm{GWh}$; the given interval results from the uncertainty due to air pressure loss in the newly added heat exchangers. For very humid climate locations, this value increased by yet another $10 \mathrm{GWh}$ per annum due to higher power savings achieved in air dryer regeneration. Within a reasonable range of air pressure loss in heat exchangers of 1 to $2 \%$, assumed technology, location in Košice, and electricity price interval of EUR 50-100/ $\mathrm{MWh}^{-1}$, simple payback period of 4 to 18 years was estimated with total investment costs amounting to over EUR 20 mil.

Calculation of the related greenhouse gases emissions' reduction included both our own heavy oil-fueled thermal power plant model and emission factors reported in the literature for given or similar fuels. As a result, a wide range of emission factors of major air pollutants was obtained, which is a far more realistic approach than a single value for every pollutant. The related final values of annual emission reduction potential in fossil fuel-based power production amounted to $\mathrm{CO}_{2} 16$ to 30 kilotons, $\mathrm{CO} 0.3$ to 2.3 tons, $\mathrm{SO}_{\mathrm{x}} 4.7$ to 187 tons, and $\mathrm{NO}_{\mathrm{x}} 11$ to 56 tons. If a renewable resources rich energy mix was considered for power production, the corresponding pollutant emissions' reduction values were reduced by 50 to $80 \%$, depending on the considered pollutant.

It can be concluded that the chosen approach to design and operation improvement of cryogenic air separation units proved to be feasible, delivering power consumption and greenhouse gases emissions' reduction with an acceptable simple payback period. Implementing the proposed changes in existing cryogenic air separation units has the potential to make oxygen production more efficient and sustainable.

Author Contributions: Conceptualization, M.V. and D.J.; methodology, M.R. and J.K.; software, D.J.; validation, M.R. and J.K.; investigation, D.J. and M.K.; data curation, D.J. and M.K.; writingoriginal draft preparation, M.V. and D.J.; writing-review and editing, M.R. and J.K.; visualization, M.K.; funding acquisition, M.V. All authors have read and agreed to the published version of the manuscript. 
Funding: This study was supported by the Slovak Research and Development Agency under the contract no. APVV-19-0170.

Institutional Review Board Statement: Not applicable.

Informed Consent Statement: Not applicable.

Data Availability Statement: All data obtained by calculations and analyses are listed directly in this study.

Conflicts of Interest: The authors declare no conflict of interest. The funders had no role in the design of the study; in the collection, analyses, or interpretation of data; in the writing of the manuscript, or in the decision to publish the results.

\section{Appendix A}

Table A1. Inlet air parameters and composition [36].

\begin{tabular}{cc}
\hline Parameter & Value \\
\hline Mass flow $\left(\mathrm{t} \mathrm{h}^{-1}\right)$ & 500 \\
Temperature $\left({ }^{\circ} \mathrm{C}\right)$ & 25 \\
Pressure $(\mathrm{kPa})$ & 100 \\
\hline Composition $(\mathrm{mol})$. & Value \\
\hline Nitrogen & 0.7686 \\
Oxygen & 0.2062 \\
Argon & 0.0092 \\
Carbon dioxide & 0.0003 \\
Water vapor & 0.0156 \\
\hline
\end{tabular}

Table A2. Inlet cooling water parameters [29].

\begin{tabular}{cc}
\hline Parameter & Value \\
\hline Mass flow $\left(\mathrm{t} \mathrm{h}^{-1}\right)$ & 4700 \\
Temperature $\left({ }^{\circ} \mathrm{C}\right)$ & 25 \\
Pressure $(\mathrm{kPa})$ & 100 \\
\hline
\end{tabular}

Table A3. Model equipment input parameters. HPC: high-pressure column; LPC: low-pressure column.

\begin{tabular}{|c|c|c|}
\hline Process Equipment & Model & Input Parameters \\
\hline Compressor & Compr & $\begin{array}{l}\text { Inlet pressure of air } \\
\text { Isentropic efficiency }\end{array}$ \\
\hline Heat exchanger & HeatX & $\begin{array}{l}\text { Outlet temperature of air } \\
\text { Pressure loss }\end{array}$ \\
\hline Multi-stream heat exchanger & MHeatX & $\begin{array}{c}\text { Outlet temperature of streams } \\
\text { Pressure loss }\end{array}$ \\
\hline Flash separator & Flash2 & Pressure \\
\hline Adsorber & Sep & Pressure \\
\hline Distillation column & $\begin{array}{c}\text { RadFrac } \\
\text { (without condenser/reboiler) }\end{array}$ & $\begin{array}{c}\text { Pressure in condenser and reboiler, Pressure loss } \\
\text { Mass flow of distillate (HPC) } \\
\text { Reboiler duty (LPC) } \\
\text { Number of stages } \\
\text { Feed stages } \\
\text { Outlet pressure of stream } \\
\text { Isentropic efficiency }\end{array}$ \\
\hline
\end{tabular}




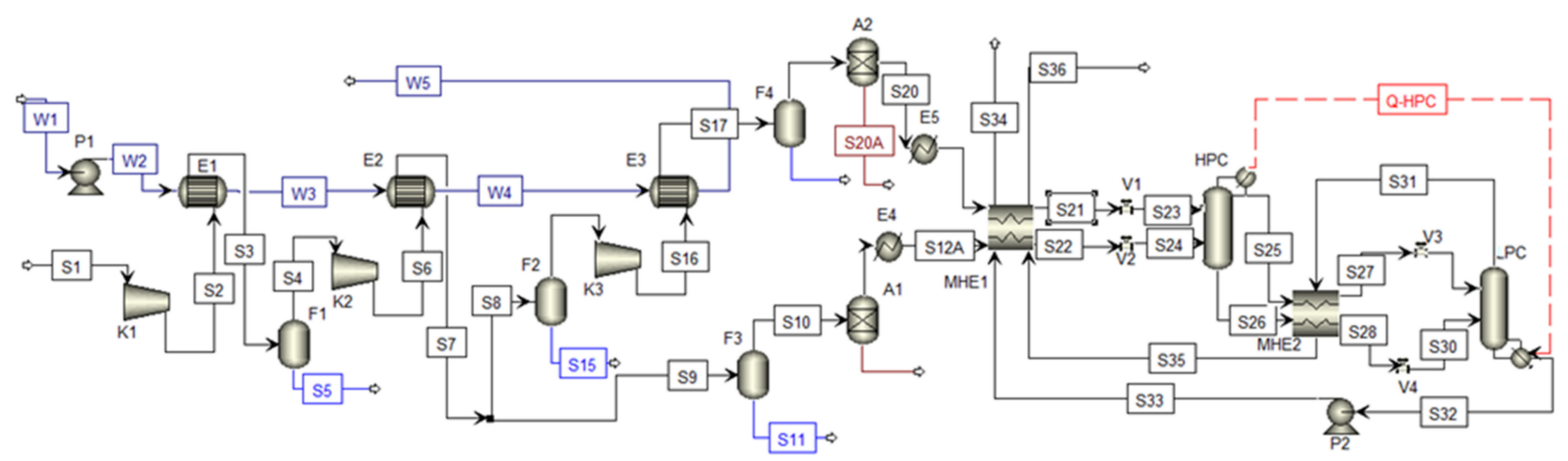

Figure A1. Modified process flow scheme. A: adsorber; E: heat exchanger; F: phase separator; HPC: high-pressure column; K: compressor; LPC: low-pressure column; MHE: multi-stream heat exchanger; Q: heat flow; P: pump; S: material stream; SS1: stream splitter; V: valve; W: cooling water stream.

\section{Appendix B}

Table A4. Parameters of absorption cooler $(\mathrm{ACH})$ placed after first compression stage. COP: coefficient of performance; USRT: U.S. refrigeration ton. Source: [63].

\begin{tabular}{|c|c|}
\hline Parameter & Value \\
\hline Model of ACH & Hot-water/135 \\
\hline USRT (U.S. refrigeration ton) & 1350 \\
\hline COP & 0.8 \\
\hline \multicolumn{2}{|c|}{ Hot water } \\
\hline Inlet temperature to generator $\left({ }^{\circ} \mathrm{C}\right)$ & 95 \\
\hline Outlet temperature from generator $\left({ }^{\circ} \mathrm{C}\right)$ & 72 \\
\hline Mass flow $\left(\mathrm{t} \mathrm{h}^{-1}\right)$ & 219.2 \\
\hline \multicolumn{2}{|c|}{ Chilled water } \\
\hline Inlet temperature to evaporator $\left({ }^{\circ} \mathrm{C}\right)$ & 13 \\
\hline Outlet temperature from evaporator $\left({ }^{\circ} \mathrm{C}\right)$ & 8 \\
\hline Volumetric flow $\left(\mathrm{m}^{3} \mathrm{~h}^{-1}\right)$ & 816.5 \\
\hline \multicolumn{2}{|c|}{ Cooling water } \\
\hline Inlet temperature $\left({ }^{\circ} \mathrm{C}\right)$ & 31 \\
\hline Outlet temperature $\left({ }^{\circ} \mathrm{C}\right)$ & 36.5 \\
\hline Volumetric flow $\left(\mathrm{m}^{3} \mathrm{~h}^{-1}\right)$ & 1658.6 \\
\hline
\end{tabular}

Table A5. Parameters of ACH placed after second compression stage. Source: [63].

\begin{tabular}{|c|c|}
\hline Parameter & Value \\
\hline Model of ACH & Hot-water/113 \\
\hline USRT (U.S. refrigeration ton) & 1125 \\
\hline $\mathrm{COP}$ & 0.8 \\
\hline \multicolumn{2}{|c|}{ Hot water } \\
\hline Inlet temperature to generator $\left({ }^{\circ} \mathrm{C}\right)$ & 95 \\
\hline Outlet temperature from generator $\left({ }^{\circ} \mathrm{C}\right)$ & 72 \\
\hline Mass flow $\left(\mathrm{t} \mathrm{h}^{-1}\right)$ & 182.6 \\
\hline \multicolumn{2}{|c|}{ Chilled water } \\
\hline Inlet temperature to evaporator $\left({ }^{\circ} \mathrm{C}\right)$ & 13 \\
\hline Outlet temperature from evaporator $\left({ }^{\circ} \mathrm{C}\right)$ & 8 \\
\hline Volumetric flow $\left(\mathrm{m}^{3} \mathrm{~h}^{-1}\right)$ & 680.4 \\
\hline \multicolumn{2}{|c|}{ Cooling water } \\
\hline Inlet temperature $\left({ }^{\circ} \mathrm{C}\right)$ & 31 \\
\hline Outlet temperature $\left({ }^{\circ} \mathrm{C}\right)$ & 36.5 \\
\hline Volumetric flow $\left(\mathrm{m}^{3} \mathrm{~h}^{-1}\right)$ & 1382.2 \\
\hline
\end{tabular}


Table A6. Parameters of cooling towers. Source: [64].

\begin{tabular}{cc}
\hline Parameter & Value \\
\hline Type of cooling tower & Fan \\
Model of cooling tower & $12 / 70 \mathrm{ZB}$ \\
Number of fans & 12 \\
Maximum cooling range $\left({ }^{\circ} \mathrm{C}\right)$ & 7 \\
Wet bulb temperature $\left({ }^{\circ} \mathrm{C}\right)$ & 21 \\
Volumetric flow of air $\left(\mathrm{m}^{3} \mathrm{~h}^{-1}\right)$ & 504,000 \\
Nominal mass flow of cooling water $\left(\mathrm{t} \mathrm{h}^{-1}\right)$ & 1225 \\
Minimum/Maximum mass flow of cooling water $\left(\mathrm{t} \mathrm{h}^{-1}\right)$ & $276 / 1476$ \\
\hline
\end{tabular}

Table A7. Parameters of cooling towers used for modeling in Aspen Plus.

\begin{tabular}{cc}
\hline Parameter & Value \\
\hline Pressure $(\mathrm{kPa})$ & 100 \\
Number of equilibrium stages & 10 \\
Mass flow of cooling water $\left(\mathrm{t} \mathrm{h}^{-1}\right)$ & 1175 \\
Inlet temperature of cooling tower $\left({ }^{\circ} \mathrm{C}\right)$ & 32.6 \\
Volumetric flow of air $\left(\mathrm{m}^{3} \mathrm{~h}^{-1}\right)$ & 504,000 \\
Inlet temperature of air $\left({ }^{\circ} \mathrm{C}\right)$ & 25 \\
\hline
\end{tabular}

Table A8. Parameters of ACH exploiting external heat. Source: [63].

\begin{tabular}{cc}
\hline Parameter & Value \\
\hline Model of ACH & Hot-water $/ 038$ \\
USRT (U.S. refrigeration ton) & 375 \\
COP & 0.8 \\
\hline Chilled water \\
\hline Inlet temperature to evaporator $\left({ }^{\circ} \mathrm{C}\right)$ \\
Outlet temperature from evaporator $\left({ }^{\circ} \mathrm{C}\right)$ \\
Volumetric flow $\left(\mathrm{m}^{3} \mathrm{~h}^{-1}\right)$ \\
\hline Cooling water \\
\hline Inlet temperature $\left({ }^{\circ} \mathrm{C}\right)$ \\
Outlet temperature $\left({ }^{\circ} \mathrm{C}\right)$ \\
Volumetric flow $\left(\mathrm{m}^{3} \mathrm{~h}^{-1}\right)$ \\
$\quad$
\end{tabular}

\section{Appendix C}

The modeled industrial combined heat and power unit includes a very high-pressure steam boiler fueled by heavy fuel oil (HFO) and an extraction-condensing steam turbine, plus auxiliary equipment (Figure A2). It includes common power plant features such as air and fuel preheating and stepwise boiler feedwater heating $[89,90]$ and it supplies the refinery with steam on three pressure levels. It has a spare condensing power production capacity of several $10^{1} \mathrm{MW}$ which can be used to produce power for the ASU operation. Since 2012, a flue gas desulfurization unit (FGD) has been operated, reducing $\mathrm{SO}_{\mathrm{x}}$ emissions by around $80 \%$ compared to the past [91]. The following assumptions were used in model construction:

- $\quad$ HFO composition in \% wt.: carbon 87; hydrogen 12; sulfur 1; HFO lower heating value: $40.5 \mathrm{GJ} \mathrm{t}^{-1}$;

- $\quad$ Combustion air excess: $30 \%$; preheated air temperature: $100{ }^{\circ} \mathrm{C}$;

- Flue gas to stack (to FGD) temperature: $190{ }^{\circ} \mathrm{C}$ (margin of around $50{ }^{\circ} \mathrm{C}$ to minimize risk of low-temperature corrosion);

- $\quad$ Steam boiler blow down rate: $1.5 \%$;

- $\quad$ Steam turbine inlet parameters: $9 \mathrm{MPa}, 530{ }^{\circ} \mathrm{C}$; 
- Steam turbine isentropic efficiency: $85 \%$ in superheated steam region and $75 \%$ in wet steam region was used to calculate enthalpies of individual bleeds and regulated extractions in the water steam chart as recently demonstrated by Baressi et al. [92]; mechanical efficiency: 95\%;

- Bleed pressure estimation: to keep a margin of $5{ }^{\circ} \mathrm{C}$ between bleed condensing temperature and water outlet temperature from water heater;

- Regulated extractions pressure: RE 1: 3.06 MPa; RE 2: $1 \mathrm{MPa}$; RE 3: 0.4 MPa;

- Temperature in turbine condenser: $30^{\circ} \mathrm{C}$;

- Stepwise condensate heating to $60,90,120,150,180$, and $210^{\circ} \mathrm{C}$ in low-temperature water heaters, in deaerator, and in high-temperature water heaters;

- Steam losses from deaerator: $6 \%$ of inlet steam;

- Internal power consumption: $5 \%$ of gross power production;

- Zero steam export from the power plant = condensing power production;

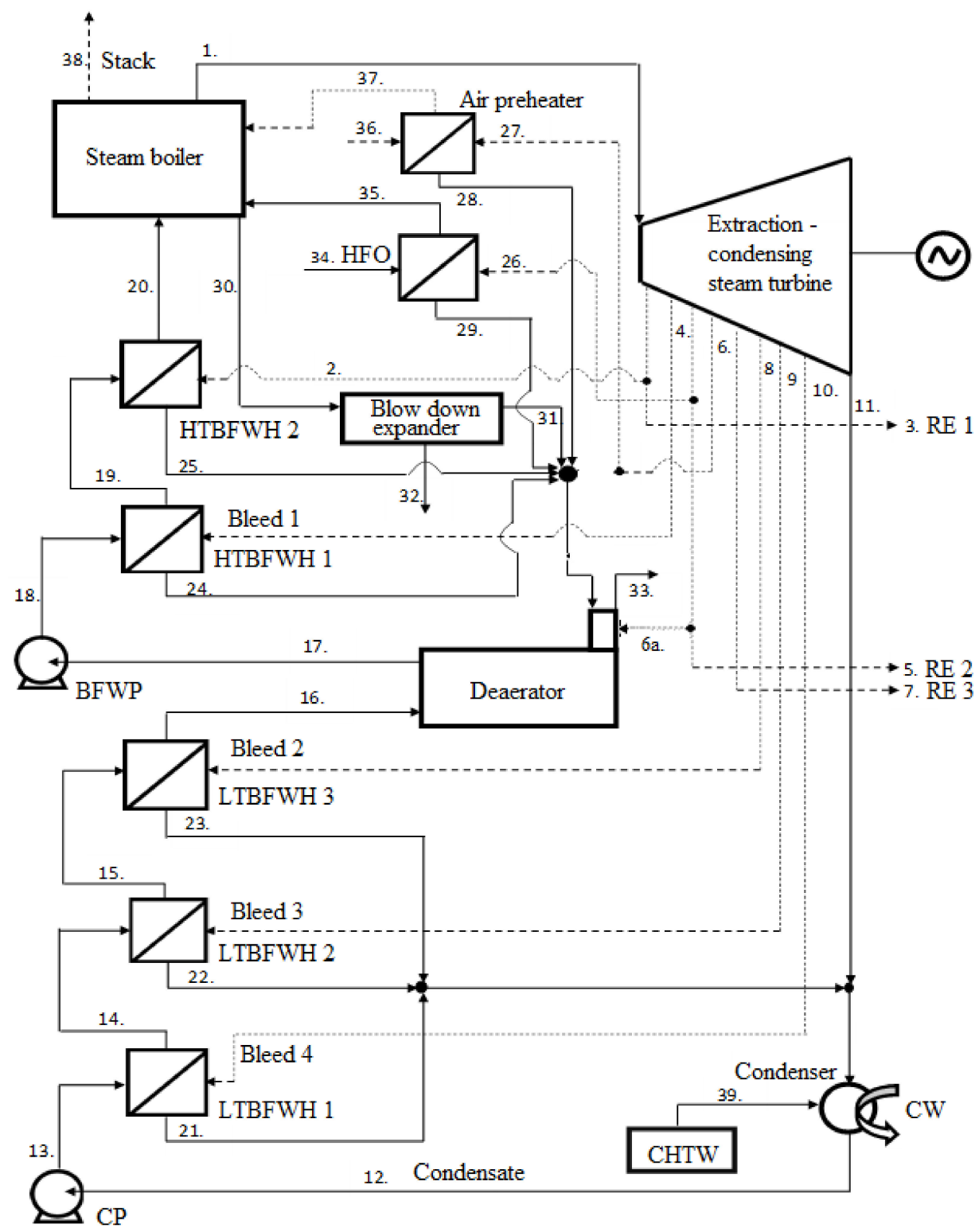

Figure A2. Model industrial thermal power plant. BFWP-boiler feedwater pump; $\mathrm{CP}$-condensate pump; CHTW—chemically treated water; CW—cooling water; HFO—heavy fuel oil; HTBFWHhigh-temperature boiler feedwater heater; LTBFWH-low-temperature boiler feedwater heater; RE-regulated extraction. Source: own elaboration. 


\section{Appendix D}

Table A9. Model verification: compression and purification section.

\begin{tabular}{|c|c|c|c|c|c|c|}
\hline \multirow{2}{*}{ Stream } & \multicolumn{3}{|c|}{ This Study } & \multicolumn{3}{|c|}{ Study [36] } \\
\hline & $m\left(t h^{-1}\right)$ & $\mathrm{t}\left({ }^{\circ} \mathrm{C}\right)$ & $\mathrm{P}(\mathrm{kPa})$ & $m\left(t h^{-1}\right)$ & $t\left({ }^{\circ} \mathrm{C}\right)$ & $\mathrm{P}(\mathrm{kPa})$ \\
\hline $\mathrm{S} 1$ & 500 & 25 & 100 & 500 & 25 & 100 \\
\hline $\mathrm{S} 2$ & 500 & 147.9 & 250 & 500 & 146 & 250 \\
\hline S3-S4 & 500 & 40 & 240 & 500 & 40 & 240 \\
\hline S5 & 0 & 40 & 240 & 0 & 40 & 240 \\
\hline S6 & 500 & 168.9 & 600 & 500 & 168.9 & 600 \\
\hline S7 & 500 & 40.0 & 590 & 500 & 40.0 & 590 \\
\hline S8 & 160 & 40 & 590 & 160 & 40 & 590 \\
\hline S9 & 340 & 40 & 590 & 340 & 40 & 590 \\
\hline $\mathrm{S} 10$ & 339.0 & 40 & 590 & 339.0 & 40 & 590 \\
\hline S11 & 976 & 40 & 590 & 1000 & 40 & 590 \\
\hline S12 & 336.5 & 40 & 590 & 336.5 & 40 & 590 \\
\hline S13 & 2.5 & 40 & 590 & 2.5 & 40 & 590 \\
\hline S14 & 159.5 & 40.0 & 590 & 159.5 & 40.0 & 590 \\
\hline S15 & 459.3 & 40 & 590 & 500 & 40 & 590 \\
\hline S16 & 159.5 & 70.7 & 750 & 159.5 & 70.8 & 750 \\
\hline S17 & 159.5 & 40 & 740 & 159.5 & 40 & 740 \\
\hline S18 & 159.3 & 40 & 740 & 159.3 & 40 & 740 \\
\hline S19 & 215.7 & 40 & 740 & 200 & 40 & 740 \\
\hline $\mathrm{S} 20$ & 158.4 & 40 & 740 & 158.4 & 40 & 740 \\
\hline S20A & 0.9 & 40 & 740 & 1.0 & 40 & 740 \\
\hline W2 & 4700 & 25.0 & 330 & 4700 & 25.0 & 330 \\
\hline W3 & 4700 & 27.6 & 320 & 4700 & 27.6 & 320 \\
\hline W4 & 4700 & 30.9 & 310 & 4700 & 30.9 & 310 \\
\hline W5 & 4700 & 31.1 & 300 & 4700 & 31.1 & 300 \\
\hline
\end{tabular}

Table A10. Model verification: cryogenic section.

\begin{tabular}{|c|c|c|c|c|c|c|}
\hline \multirow{2}{*}{ Stream } & \multicolumn{3}{|c|}{ This Study } & \multicolumn{3}{|c|}{ Study [36] } \\
\hline & $m\left(t^{-1}\right)$ & $t\left({ }^{\circ} \mathrm{C}\right)$ & $\mathbf{P}(\mathbf{k P a})$ & $m\left(t^{-1}\right)$ & $t\left({ }^{\circ} \mathrm{C}\right)$ & $P(\mathbf{k P a})$ \\
\hline S21 & 158.4 & -171.7 & 730 & 158.4 & -171.7 & 730 \\
\hline $\mathrm{S} 22$ & 336.5 & -160 & 580 & 336.5 & -160 & 580 \\
\hline $\mathrm{S} 23$ & 158.4 & -174.9 & 580 & 158.4 & -174.9 & 580 \\
\hline S24 & 336.5 & -160 & 580 & 336.5 & -160 & 580 \\
\hline S25 & 199.1 & -177.5 & 560 & 199.1 & -177.5 & 560 \\
\hline S26 & 295.8 & -173.3 & 580 & 295.8 & -173.3 & 580 \\
\hline S27 & 199.1 & -185.7 & 550 & 199.1 & -185.7 & 550 \\
\hline $\mathrm{S} 28$ & 295.8 & -180.6 & 570 & 295.8 & -180.6 & 570 \\
\hline S29 & 199.1 & -192.1 & 150 & 199.1 & -192.1 & 150 \\
\hline $\mathrm{S} 30$ & 295.8 & -189.0 & 150 & 295.8 & -189.0 & 150 \\
\hline S31 & 380.4 & -193.9 & 120 & 378.6 & -194.1 & 120 \\
\hline S32 & 114.5 & -179.3 & 150 & 116.3 & -179.3 & 150 \\
\hline $\mathrm{S} 33$ & 114.4 & -179.2 & 290 & 116.3 & -179.2 & 480 \\
\hline S34 & 114.4 & 38.3 & 280 & 116.3 & 39.0 & 470 \\
\hline S35 & 380.4 & -174.9 & 110 & 378.6 & -175 & 110 \\
\hline S36 & 380.4 & 38.0 & 100 & 378.6 & 39.0 & 100 \\
\hline
\end{tabular}


Table A11. Model verification: molar stream composition-HPC and LPC column.

\begin{tabular}{ccccccc}
\hline \multirow{2}{*}{ Stream } & \multicolumn{3}{c}{ This Study } & \multicolumn{3}{c}{ Study [36] } \\
\cline { 2 - 6 } & $\mathbf{N}_{\mathbf{2}}$ & $\mathbf{O}_{\mathbf{2}}$ & $\mathbf{A r}$ & $\mathbf{N}_{\mathbf{2}}$ & $\mathbf{O}_{\mathbf{2}}$ & $\mathbf{A r}$ \\
\hline S23 & 0.78 & 0.21 & 0.01 & 0.78 & 0.21 & 0.01 \\
S24 & 0.78 & 0.21 & 0.01 & 0.78 & 0.21 & 0.01 \\
S25 & 1.00 & 0.00 & 0.00 & 0.99 & 0.00 & 0.00 \\
S26 & 0.63 & 0.36 & 0.01 & 0.63 & 0.36 & 0.01 \\
\hline S29 & 1.00 & 0.00 & 0.00 & 0.99 & 0.00 & 0.00 \\
S30 & 0.63 & 0.36 & 0.01 & 0.63 & 0.36 & 0.01 \\
S31 & 1.00 & 0.00 & 0.01 & 0.99 & 0.00 & 0.00 \\
S32 & - & 0.99 & 0.01 & 0.00 & 0.99 & 0.00 \\
\hline
\end{tabular}

\section{Appendix E}

Table A12. Key operating parameters of cooling towers implemented in the model with ACH.

\begin{tabular}{cccc}
\hline Stream & $\mathbf{m}\left(\mathbf{t} \mathbf{h}^{-\mathbf{1}}\right)$ & $\mathbf{t}\left({ }^{\circ} \mathbf{C}\right)$ & $\mathbf{P}(\mathbf{k P a})$ \\
\hline $\mathrm{W} 12$ & 1175.1 & 33.0 & 100 \\
$\mathrm{~S} 37\left(\mathrm{~m}^{3} \mathrm{~h}^{-1}\right)$ & 504,000 & 25.0 & 100 \\
$\mathrm{~W} 16$ & 1161.6 & 25.3 & 100 \\
$\mathrm{~S} 41$ & 598.9 & 33.1 & 100 \\
\hline
\end{tabular}

Table A13. Comparison of power consumption for adsorber regeneration in basic model (without $\mathrm{ACH})$ and in the model with $\mathrm{ACH}$.

\begin{tabular}{ccc}
\hline Parameter (without $\mathbf{A C H})$ & A1 & A2 \\
\hline Inlet air humidity $\left(\mathrm{g} \mathrm{kg}^{-1}\right)$ & 6.845 & 5.632 \\
Mass flow of adsorbed water $\left(\mathrm{kg} \mathrm{h}^{-1}\right)$ & 2304.7 & 892.4 \\
Electrical power input for adsorber regeneration $(\mathrm{MW})$ & 3.706 & 1.435 \\
\hline Parameter (with ACH) & $\mathbf{A 1}$ & $\mathbf{A 2}$ \\
\hline Inlet air humidity $\left(\mathrm{g} \mathrm{kg}^{-1}\right)$ & 1.545 & 1.545 \\
Mass flow of adsorbed water $\left(\mathrm{kg} \mathrm{h}^{-1}\right)$ & 520.3 & 244.8 \\
Electrical power input for adsorber regeneration $(\mathrm{MW})$ & 0.836 & 0.394 \\
\hline Electrical power input savings (MW) & 2.869 & 1.041 \\
Annual electrical power savings (MWh) & $25,138.1$ & 9123.2 \\
\hline Total annual electrical power savings $(\mathrm{MWh})$ & \multicolumn{2}{c}{$34,261.3$} \\
\hline
\end{tabular}

Table A14. Recalculation of power input for adsorber regeneration without ACH employing ambient air humidity dataset presented in Figures 4-6.

\begin{tabular}{|c|c|c|}
\hline Parameter & A1 & A2 \\
\hline Calculated inlet air humidity $\left(\mathrm{g} \mathrm{kg}^{-1}\right)$ & 6.845 & 5.632 \\
\hline Mass flow of adsorbed water $\left(\mathrm{kg} \mathrm{h}^{-1}\right)$ & 2304.7 & 892.4 \\
\hline Calculated electrical power input for adsorber regeneration (MW) & 3.706 & 1.435 \\
\hline Time of the year with higher measured air humidity (\%) & 38.5 & 46.5 \\
\hline Time of the year with lower measured air humidity $(\%)$ & 61.5 & 53.5 \\
\hline Average air humidity for electrical power savings recalculation $\left(\mathrm{g} \mathrm{kg}^{-1}\right)$ & 4.02 & 3.66 \\
\hline Calculated average mass flow of adsorbed water for time of the year with lower air humidity $\left(\mathrm{kg} \mathrm{h}^{-1}\right)$ & 1356.3 & 580.7 \\
\hline $\begin{array}{c}\text { Calculated average electrical power input for adsorber regeneration for time of the year with } \\
\text { lower air humidity (MW) }\end{array}$ & 2.181 & 0.934 \\
\hline Recalculated average electrical power input for adsorber regeneration (MW) & 2.767 & 1.167 \\
\hline
\end{tabular}




\section{References}

1. Wang, Z.; Wang, W.; Qin, W.; Gui, W.; Xu, S.; Yang, C.; Zhang, Z.; Wang, Y.; Zheng, J.; Liu, X. Analysis of carbon footprint reduction for three novel air separation columns. Sep. Purif. Technol. 2021, 262, 118318. [CrossRef]

2. Alqaheem, Y.; Alomair, A.A. Sealing perovskite membranes for long-term oxygen separation from air. Chem. Pap. 2020, 74, 4159-4168. [CrossRef]

3. Banaszkiewicz, T.; Chorowski, M. Energy Consumption of Air-Separation Adsorption Methods. Entropy 2018, 20, 232. [CrossRef] [PubMed]

4. Janusz-Szymańska, K.; Dryjańska, A. Possibilities for improving the thermodynamic and economic characteristics of an oxy-type power plant with a cryogenic air separation unit. Energy 2015, 85, 45-61. [CrossRef]

5. Adamson, R.; Hobbs, M.; Silcock, A.; Willis, M.J. Steady-state optimisation of a multiple cryogenic air separation unit and compressor plant. Appl. Energy 2017, 189, 221-232. [CrossRef]

6. Fernandez-Barquin, A.; Casado-Coterillo, C.; Valencia, S.; Irabien, A. Mixed Matrix Membranes for O(2)/N(2) Separation: The Influence of Temperature. Membranes 2016, 6, 28. [CrossRef]

7. Portillo, E.; Gallego Fernández, L.M.; Vega, F.; Alonso-Fariñas, B.; Navarrete, B. Oxygen transport membrane unit applied to oxy-combustion coal power plants: A thermodynamic assessment. J. Environ. Chem. Eng. 2021, 9, 105266. [CrossRef]

8. Singla, R.; Chowdhury, K. Enhanced oxygen recovery and energy efficiency in a reconfigured single column air separation unit producing pure and impure oxygen simultaneously. Chem. Eng. Process. Process Intensif. 2021, 162, 108354. [CrossRef]

9. Ghoniem, A.F.; Zhao, Z.; Dimitrakopoulos, G. Gas oxy combustion and conversion technologies for low carbon energy: Fundamentals, modeling and reactors. Proc. Combust. Inst. 2019, 37, 33-56. [CrossRef]

10. Cormos, C.-C. Techno-Economic Evaluations of Copper-Based Chemical Looping Air Separation System for Oxy-Combustion and Gasification Power Plants with Carbon Capture. Energies 2018, 11, 3095. [CrossRef]

11. Castillo, R. Thermodynamic analysis of a hard coal oxyfuel power plant with high temperature three-end membrane for air separation. Appl. Energy 2011, 88, 1480-1493. [CrossRef]

12. Markewitz, P.; Marx, J.; Schreiber, A.; Zapp, P. Ecological evaluation of coal-fired Oxyfuel power plants -Cryogenic versus membrane-based air separation. Energy Procedia 2013, 37, 2864-2876. [CrossRef]

13. Kubicek, M.; Bork, A.H.; Rupp, J.L.M. Perovskite oxides-A review on a versatile material class for solar-to-fuel conversion processes. J. Mater. Chem. A 2017, 5, 11983-12000. [CrossRef]

14. Bush, H.E.; Datta, R.; Loutzenhiser, P.G. Aluminum-doped strontium ferrites for a two-step solar thermochemical air separation cycle: Thermodynamic characterization and cycle analysis. Sol. Energy 2019, 188, 775-786. [CrossRef]

15. Ezbiri, M.; Allen, K.M.; Gàlvez, M.E.; Michalsky, R.; Steinfeld, A. Design Principles of Perovskites for Thermochemical Oxygen Separation. ChemSusChem 2015, 8, 1966-1971. [CrossRef] [PubMed]

16. Bulfin, B.; Lapp, J.; Richter, S.; Gubàn, D.; Vieten, J.; Brendelberger, S.; Roeb, M.; Sattler, C. Air separation and selective oxygen pumping via temperature and pressure swing oxygen adsorption using a redox cycle of $\mathrm{SrFeO}_{3}$ perovskite. Chem. Eng. Sci. 2019, 203, 68-75. [CrossRef]

17. Brough, D.; Jouhara, H. The aluminium industry: A review on state-of-the-art technologies, environmental impacts and possibilities for waste heat recovery. Int. J. Ther. 2020, 1-2, 100007. [CrossRef]

18. Dzurňák, R.; Varga, A.; Kizek, J.; Jablonský, G.; Lukáč, L. Influence of Burner Nozzle Parameters Analysis on the Aluminium Melting Process. Appl. Sci. 2019, 9, 1614. [CrossRef]

19. Poskart, A.; Radomiak, H.; Niegodajew, P.; Zajemska, M.; Musiał, D. The Analysis of Nitrogen Oxides Formation During Oxygen-Enriched Combustion of Natural Gas. Arch. Metall. Mater. 2016, 61, 1925-1930. [CrossRef]

20. Dzurňák, R.; Varga, A.; Jablonský, G.; Variny, M.; Pástor, M.; Lukáč, L. Analyzing the Formation of Gaseous Emissions during Aluminum Melting Process with Utilization of Oxygen-Enhanced Combustion. Metals 2021, 11, 242. [CrossRef]

21. Allam, R.; Martin, S.; Forrest, B.; Fetvedt, J.; Lu, X.; Freed, D.; Brown, G.W.; Sasaki, T.; Itoh, M.; Manning, J. Demonstration of the Allam Cycle: An Update on the Development Status of a High Efficiency Supercritical Carbon Dioxide Power Process Employing Full Carbon Capture. Energy Procedia 2017, 114, 5948-5966. [CrossRef]

22. Carnero, M.C.; Gómez, A. Optimization of Decision Making in the Supply of Medicinal Gases Used in Health Care. Sustainability 2019, 11, 2952. [CrossRef]

23. Singla, R.; Chowdhury, K. Determining design criteria to reduce power and cost in filling high-pressure oxygen cylinders directly from cryogenic air separation plants. Cryogenics 2021, 116, 103299. [CrossRef]

24. Feinmann, J. How COVID-19 revealed the scandal of medical oxygen supplies worldwide. BMJ 2021, 373, n1166. [CrossRef]

25. Graham, H.R.; Bagayana, S.M.; Bakare, A.A.; Olayo, B.O.; Peterson, S.S.; Duke, T.; Falade, A.G. Improving Hospital Oxygen Systems for COVID-19 in Low-Resource Settings: Lessons from the Field. Glob. Health Sci. Pract. 2020, 8, 858-862. [CrossRef]

26. Nakkazi, E. Oxygen supplies and COVID-19 mortality in Africa. Lancet Respir. Med. 2021, 9, e39. [CrossRef]

27. Bhuyan, A. COVID-19: India looks to import oxygen as cases surge, overwhelming hospitals. BMJ 2021, 373, n1061. [CrossRef] [PubMed]

28. Vemula, R.R.; Urich, M.D.; Kothare, M.V. Experimental design of a "Snap-on" and standalone single-bed oxygen concentrator for medical applications. Adsorption 2021, 27, 1-10. [CrossRef] [PubMed]

29. Shakil, M.H.; Munim, Z.H.; Tasnia, M.; Sarowar, S. COVID-19 and the environment: A critical review and research agenda. Sci. Total Environ. 2020, 745, 141022. [CrossRef] [PubMed] 
30. Balys, M.; Brodawka, E.; Korzeniewska, A.; Szczurowski, J.; Zarebska, K. LCA and economic study on the local oxygen supply in Central Europe during the COVID-19 pandemic. Sci. Total Environ. 2021, 786, 147401. [CrossRef] [PubMed]

31. Farquharson, D.; Jaramillo, P.; Schivley, G.; Klima, K.; Carlson, D.; Samaras, C. Beyond Global Warming Potential: A Comparative Application of Climate Impact Metrics for the Life Cycle Assessment of Coal and Natural Gas Based Electricity. J. Ind. Ecol. 2017, 21, 857-873. [CrossRef]

32. Hnydiuk-Stefan, A.; Składzień, J. Analysis of supercritical coal fired oxy combustion power plant with cryogenic oxygen unit and turbo-compressor. Energy 2017, 128, 271-283. [CrossRef]

33. Caspari, A.; Offermanns, C.; Schäfer, P.; Mhamdi, A.; Mitsos, A. A flexible air separation process: 1. Design and steady-state optimizations. AIChE J. 2019, 65, e16705. [CrossRef]

34. Ding, G.; He, B.; Cao, Y.; Wang, C.; Su, L.; Duan, Z.; Song, J.; Tong, W.; Li, X. Process simulation and optimization of municipal solid waste fired power plant with oxygen/carbon dioxide combustion for near zero carbon dioxide emission. Energy Convers. Manag. 2018, 157, 157-168. [CrossRef]

35. Goodarzia, G.; Dehghani, S.; Akbarzadeh, A.; Date, A. Energy Saving Opportunities in air Drying Process in High-pressure Compressors. Energy Procedia 2017, 110, 428-433. [CrossRef]

36. Hamayun, M.H.; Ramzan, N.; Hussain, M.; Faheem, M. Evaluation of Two-Column Air Separation Processes Based on Exergy Analysis. Energies 2020, 13, 6361. [CrossRef]

37. Tafone, A.; Dal Magro, F.; Romagnoli, A. Integrating an oxygen enriched waste to energy plant with cryogenic engines and Air Separation Unit: Technical, economic and environmental analysis. Appl. Energy 2018, 231, 423-432. [CrossRef]

38. Adhikari, B.; Orme, C.J.; Klaehn, J.R.; Stewart, F.F. Technoeconomic analysis of oxygen-nitrogen separation for oxygen enrichment using membranes. Sep. Purif. Technol. 2021, 268, 118703. [CrossRef]

39. Kotowicz, J.; Michalski, S.; Brzęczek, M. The Characteristics of a Modern Oxy-Fuel Power Plant. Energies 2019, 12, 3374. [CrossRef]

40. Wang, C.; Akkurt, N.; Zhang, X.; Luo, Y.; She, X. Techno-economic analyses of multi-functional liquid air energy storage for power generation, oxygen production and heating. Appl. Energy 2020, 275, 115392. [CrossRef]

41. Banaszkiewicz, T. The Possible Coupling of LNG Regasification Process with the TSA Method of Oxygen Separation from Atmospheric Air. Entropy 2021, 23, 350. [CrossRef]

42. Elhelw, M.; Alsanousie, A.A.; Attia, A. Novel operation control strategy for conjugate high-low pressure air separation columns at different part loads. Alex. Eng. J. 2020, 59, 613-633. [CrossRef]

43. Skorek-Osikowska, A.; Bartela, Ł.; Kotowicz, J. A comparative thermodynamic, economic and risk analysis concerning implementation of oxy-combustion power plants integrated with cryogenic and hybrid air separation units. Energy Convers. Manag. 2015, 92, 421-430. [CrossRef]

44. Dib, G.; Haberschill, P.; Rullière, R.; Revellin, R. Thermodynamic investigation of quasi-isothermal air compression/expansion for energy storage. Energy Convers. Manag. 2021, 235, 114027. [CrossRef]

45. Rong, Y.; Zhi, X.; Wang, K.; Zhou, X.; Cheng, X.; Qiu, L.; Chi, X. Thermoeconomic analysis on a cascade energy utilization system for compression heat in air separation units. Energy Convers. Manag. 2020, 213, 112820. [CrossRef]

46. Rong-Yang, Y.; Wu, Q.; Zhou, X.; Fang, S.; Wang, K.; Qiu, L.; Zhi, X. Research on optimization of self-utilization performance of air compression waste heat in air separation system. CIESC J. 2021, 72, 1654-1666. [CrossRef]

47. Escudero, A.I.; Espatolero, S.; Romeo, L.M. Oxy-combustion power plant integration in an oil refinery to reduce $\mathrm{CO}_{2}$ emissions Int. J. Greenh. Gas Control 2016, 45, 118-129. [CrossRef]

48. Zhou, X.; Rong, Y.; Fang, S.; Wang, K.; Zhi, X.; Qiu, L.; Chi, X. Thermodynamic analysis of an organic Rankine-vapor compression cycle (ORVC) assisted air compression system for cryogenic air separation units. Appl. Therm. Eng. 2021, 189, 116678. [CrossRef]

49. Hamels, S.; Himpe, E.; Laverge, J.; Delghust, M.; Van den Brande, K.; Janssens, A.; Albrecht, J. The use of primary energy factors and $\mathrm{CO}_{2}$ intensities for electricity in the European context-A systematic methodological review and critical evaluation of the contemporary literature. Renew. Sustain. Energy Rev. 2021, 146, 111182. [CrossRef]

50. Ådahl, A.; Harvey, S.; Berntsson, T. Process industry energy retrofits: The importance of emission baselines for greenhouse gas reductions. Energy Policy 2004, 32, 1375-1388. [CrossRef]

51. Smith, C.N.; Hittinger, E. Using marginal emission factors to improve estimates of emission benefits from appliance efficiency upgrades. Energy Effic. 2019, 12, 585-600. [CrossRef]

52. Seckinger, N.; Radgen, P. Dynamic Prospective Average and Marginal GHG Emission Factors-Scenario-Based Method for the German Power System until 2050. Energies 2021, 14, 2527. [CrossRef]

53. Vuarnoz, D.; Jusselme, T. Dataset concerning the hourly conversion factors for the cumulative energy demand and its nonrenewable part, and hourly GHG emission factors of the Swiss mix during a one year period (2015-2016). Data Brief 2018, 21, 1026-1028. [CrossRef]

54. Song, Q.; Wang, Z.; Li, J.; Duan, H.; Yu, D.; Liu, G. Comparative life cycle GHG emissions from local electricity generation using heavy oil, natural gas, and MSW incineration in Macau. Renew. Sustain. Energy Rev. 2018, 81, 2450-2459. [CrossRef]

55. Chen, L.; Wemhoff, A.P. Predicting embodied carbon emissions from purchased electricity for United States counties. Appl. Energy 2021, 292, 116898. [CrossRef]

56. Rehman, H.U.; Hirvonen, J.; Jokisalo, J.; Kosonen, R.; Sirén, K. EU Emission Targets of 2050: Costs and CO ${ }_{2}$ Emissions Comparison of Three Different Solar and Heat Pump-Based Community-Level District Heating Systems in Nordic Conditions. Energies 2020, 13, 4167. [CrossRef] 
57. Hamels, S. $\mathrm{CO}_{2}$ Intensities and Primary Energy Factors in the Future European Electricity System. Energies 2021, $14,2165$. [CrossRef]

58. Constantin, D.E.; Bocaneala, C.; Voiculescu, M.; Rosu, A.; Merlaud, A.; Roozendael, M.V.; Georgescu, P.L. Evolution of SO 2 and NOx Emissions from Several Large Combustion Plants in Europe during 2005-2015. Int. J. Env. Res Public Health 2020, 17, 3630. [CrossRef] [PubMed]

59. Leerbeck, K.; Bacher, P.; Junker, R.G.; Tveit, A.; Corradi, O.; Madsen, H.; Ebrahimy, R. Control of Heat Pumps with $\mathrm{CO}_{2}$ Emission Intensity Forecasts. Energies 2020, 13, 2851. [CrossRef]

60. Lieskovský, M.; Trenčiansky, M.; Majlingová, A.; Jankovský, J. Energy Resources, Load Coverage of the Electricity System and Environmental Consequences of the Energy Sources Operation in the Slovak Republic-An Overview. Energies 2019, 12, 1701. [CrossRef]

61. Kim, H.; Cho, H.J.; Narayanan, S.; Yang, S.; Furukawa, H.; Schiffres, S.; Li, X.; Zhang, Y.B.; Jiang, J.; Yaghi, O.M.; et al. Characterization of Adsorption Enthalpy of Novel Water-Stable Zeolites and Metal-Organic Frameworks. Sci. Rep. 2016, 6, 19097. [CrossRef]

62. DT GROUP. Desiccant Dehumidifier. Available online: https://destech.eu/our-products/?gclid=EAIaIQobChMIi5SO27Oj8 AIVBBd7Ch2vawAgEAAYASAAEgJboPD_BwE (accessed on 30 April 2021).

63. LG HVAC Solution. Absorption Chiller. Available online: https://www.lg.com/global/business/download/resources/sac/ Catalogue_Absorption\%20Chillers_ENG_F.pdf (accessed on 28 March 2021).

64. GOHL. Cooling Tower Brochure. Available online: https://steelsoft.rs/pdf/CoolingTower_DT_GB.pdf (accessed on 1 April 2021).

65. Queiroz, J.A.; Rodrigues, V.M.S.; Matos, H.A.; Martins, F.G. Modeling of existing cooling towers in ASPEN PLUS using an equilibrium stage method. Energy Convers. Manag. 2012, 64, 473-481. [CrossRef]

66. Brueckner, S.; Arbter, R.; Pehnt, M.; Laevemann, E. Industrial waste heat potential in Germany-A bottom-up analysis. Energy Effic. 2016, 10, 513-525. [CrossRef]

67. Law, R.; Harvey, A.; Reay, D. A knowledge-based system for low-grade waste heat recovery in the process industries. Appl. Therm. Eng. 2016, 94, 590-599. [CrossRef]

68. U.S. Department of Energy. Absorption Chillers for CHP Systems. Available online: https://www.energy.gov/sites/prod/files/20 17/06/f35/CHP-Absorption\%20Chiller-compliant.pdf (accessed on 30 April 2021).

69. Peters, M.S.; Timmerhaus, K.D.; West, R.E. Plant Design and Economics for Chemical Engineers, 5th ed.; McGraw-Hill: New York, NY, USA, 2003; ISBN 0-07-239266-5.

70. National Bank of Slovak Republic. Exchange Rates. 2021. Available online: https://www.nbs.sk/sk (accessed on 30 April 2021).

71. Economic Indicators: Chemical Engineering Plant Cost Index 2016. 2017. Available online: https://www.scribd.com/document/ 352561651/CEPCI-June-2017-Issue (accessed on 30 April 2021).

72. Mignard, D. Correlating the chemical engineering plant cost index with macro-economic indicators. Chem. Eng. Res. Des. 2014, 92, 285-294. [CrossRef]

73. Loh, H.P.; Lyons, J.; White, C.W. Process Equipment Cost Estimation Final Report; National Energy Technology Laboratory, U.S. Department of Energy: Pittsburgh, PA, USA, 2002. [CrossRef]

74. Typical Overall Heat Transfer Coefficients. Available online: http://www.engineeringpage.com/technology/thermal/transfer. html (accessed on 1 May 2021).

75. Keshavarzian, S.; Verda, V.; Colombo, E.; Razmjoo, P. Fuel Saving due to pinch analysis and heat recovery in a petrochemical company. In Proceedings of the ECOS 2015-28th International Conference on Efficiency, Cost, Optimization, Simulation and Environmental Impact of Energy Systems, Pau, France, 30 June-3 July 2015. [CrossRef]

76. Perry, R.H.; Green, D.W.; Maloney, J.O. Process Economics. In Perry's Chemical Engineers' Handbook, 7th ed.; McGraw-Hill Professional: London, UK, 1997; ISBN 0-07-049841-5.

77. Mach, V. EDISON Rekonstrukce a Modernizace Teplárny v Areálu SLOVNAFT, a.s. Available online: http:/ / old.allforpower.cz/ UserFiles/files/2011/mach.pdf (accessed on 28 June 2021). (In Slovak).

78. Automated Monitoring System Reports 2012-2016. Available online: https://slovnaft.sk/sk/o-nas/trvalo-udrzatelny-rozvoj/ spravy-a-ukazovatele/ams-protokoly/022-teplaren-fgd2/ (accessed on 28 June 2021). (In Slovak).

79. Automated Monitoring System Report 2018. Available online: https://slovnaft.sk/images/slovnaft/pdf/o_nas/trvalo_ udrzatelny_rozvoj/informacie_o_zivotnom_prostredi/inf_verejnosti_19_emisie.pdf (accessed on 28 June 2021). (In Slovak).

80. KOMFOVENT. Heat Exchangers-Installation and Operation Guide. Available online: https://www.tzbprodukt.sk/ attachments /7e8c6eee69a8544570e75f23050ad23b6b374a67/store/c6587d8f720999f250390d79f500627fbe2691cc05a94711ee2df2 e5ec0a/DCF_DCW_DH_DHCW_SVK_navod.pdf (accessed on 1 April 2021). (In Slovak).

81. EMBER—Daily Carbon Prices. Available online: https:/ / ember-climate.org/data/carbon-price-viewer/ (accessed on 1 July 2021). (In Slovak).

82. Espatolero, S.; Cortés, C.; Romeo, L.M. Optimization of boiler cold-end and integration with the steam cycle in supercritical units. Appl. Energy 2010, 87, 1651-1660. [CrossRef]

83. Variny, M.; Jediná, D.; Kizek, J.; Illés, P.; Lukáč, L.; Janošovský, J.; Lesný, M. An Investigation of the Techno-Economic and Environmental Aspects of Process Heat Source Change in a Refinery. Processes 2019, 7, 776. [CrossRef]

84. Campbell, P.E.; McMullan, J.T.; Williams, B.C. Concept for a competitive coal fired integrated gasification combined cycle power plant. Fuel 2000, 79, 1031-1040. [CrossRef] 
85. Strachan, N.; Farrell, A. Emissions from distributed vs. centralized generation: The importance of system performance. Energy Policy 2006, 34, 2677-2689. [CrossRef]

86. Huber, J.; Lohmann, K.; Schmidt, M.; Weinhardt, C. Carbon efficient smart charging using forecasts of marginal emission factors. J. Clean. Prod. 2021, 284, 124766. [CrossRef]

87. Zajemska, M.; Musiał, D.; Radomiak, H.; Poskart, A.; Wyleciał, T.; Urbaniak, D. Formation of Pollutants in the Process of Co-Combustion of Different Biomass Grades. Pol. J. Environ. Stud. 2014, 23, 1445-1448.

88. Křrumal, K.; Mikuška, P.; Horák, J.; Hopan, F.; Krpec, K. Comparison of emissions of gaseous and particulate pollutants from the combustion of biomass and coal in modern and old-type boilers used for residential heating in the Czech Republic, Central Europe. Chemosphere 2019, 229, 51-59. [CrossRef] [PubMed]

89. Medica-Viola, V.; Baressi Šegota, S.; Mrzljak, V.; Štifanić, D. Comparison of conventional and heat balance based energy analyses of steam turbine. Pomorstvo 2020, 34, 74-85. [CrossRef]

90. Kwak, H. Exergetic and thermoeconomic analyses of power plants. Energy 2003, 28, 343-360. [CrossRef]

91. Industrial Power Plant Modernization and Sulphur Emissions Reduction. Available online: https://www.energia.sk/teplaren-vareali-slovnaftu-plni-ekologicke-poziadavky-eu/ (accessed on 28 June 2021). (In Slovak).

92. Baressi Šegota, S.; Lorencin, I.; Anđelić, N.; Mrzljak, V.; Car, Z. Improvement of Marine Steam Turbine Conventional Exergy Analysis by Neural Network Application. J. Mar. Sci. Eng. 2020, 8, 884. [CrossRef] 